\title{
The Potential Use of Plant Natural Products and Plant Extracts with Antioxidant Properties for the Prevention/Treatment of Neurodegenerative Diseases: In Vitro, In Vivo and Clinical Trials
}

\author{
Franziska Pohl and Paul Kong Thoo Lin * \\ School of Pharmacy and Life Sciences, Robert Gordon University, Aberdeen AB10 7GJ, UK; f.pohl@rgu.ac.uk \\ * Correspondence: p.v.s.kong-thoo-lin@rgu.ac.uk; Tel.: +44-122-426-2818 \\ Academic Editor: Isabel C.F.R. Ferreira \\ Received: 8 November 2018; Accepted: 30 November 2018; Published: 11 December 2018

\begin{abstract}
Neurodegenerative disorders, including Alzheimer's disease, Parkinson's disease and Huntington's disease, present a major health issue and financial burden for health care systems around the world. The impact of these diseases will further increase over the next decades due to increasing life expectancies. No cure is currently available for the treatment of these conditions; only drugs, which merely alleviate the symptoms. Oxidative stress has long been associated with neurodegeneration, whether as a cause or as part of the downstream results caused by other factors. Thus, the use of antioxidants to counter cellular oxidative stress within the nervous system has been suggested as a potential treatment option for neurological disorders. Over the last decade, significant research has focused on the potential use of natural antioxidants to target oxidative stress. However, clinical trial results have lacked success for the treatment of patients with neurological disorders. The knowledge that natural extracts show other positive molecular activities in addition to antioxidant activity, however, has led to further research of natural extracts for their potential use as prevention or treatment/management of neurodegenerative diseases. This review will cover several in vitro and in vivo research studies, as well as clinical trials, and highlight the potential of natural antioxidants.
\end{abstract}

Keywords: antioxidants; natural products; in vitro; in vivo; clinical trials; plant extracts; phytochemicals; phenolics; Ginkgo biloba; secondary metabolites

\section{Introduction}

This review aims to give an overview on the importance of oxidative stress and its relevance in neurodegenerative disease. One option for counteracting oxidative stress is the application of natural products obtained from plant extracts. These have been thoroughly tested in vitro (chemical antioxidant activity and cell systems) and in vivo (animal disease models) and have shown promising results. However, results from clinical trial studies have been less successful. Here, recent research on natural extracts, and their potential pitfalls in clinical trials, are discussed.

\section{Neurodegenerative Disease}

Neurodegenerative disease is a heterogeneous group of disorders that are caused by the degradation and subsequent loss of neurons. These changes in the human brain can lead to cognitive or functional decline of the patient over time. The question as to why some people develop neurodegenerative disease and some do not has only partially been answered. While some neurodegenerative diseases can be due to genetic mutations, some are also associated with hazardous living environments. However, some of 
the causes are still unknown. This is why it is important to (i) study the reasons behind these conditions, and (ii) run drug trials of compounds that might have potential to cure, prevent, or at least delay the onset of neurodegenerative diseases [1].

\subsection{A Burden on Health Organizations without Current Cure}

Neurodegenerative disorders, including Alzheimer's disease (AD), Parkinson's disease (PD) and Huntington's disease (HD), present a major health and financial burden to every health service organization in the world. Due to extended health research and better living conditions in general, the average human life span has increased by about 30 years in the 20th century in countries like USA, Canada, Australia, New Zealand and western Europe [2]. Although this is seen as a great accomplishment, it comes as a double-edged sword, since those diseases most common in the older generation (late onset) are also on the rise. Since many neurological disorders are late-onset diseases, their occurrence will rise in very large numbers over the next century. For example, the total number of AD patients globally is estimated to be well over 100 million by 2050 [3]. However, AD is not the only disease for which the numbers will increase. A paper by Dorsey et al., "Projected number of people with Parkinson's disease in the most populous nations, 2005 through 2030", shows similar results. The number of PD patients will double or even increase above that for countries such as China, India and Indonesia [4].

Just like for AD, there is no cure or prevention available for Parkinson's patients; only the symptoms can be alleviated via drugs treatment or surgery. The lack of knowledge and research in this area has resulted in the slow drug development for neurological research. When the list of 1355 drugs newly approved between 1981 and 2010 [5] is considered, it is interesting to note that anticancer compounds, no matter whether the drug is from natural origins or synthetic (128), are the highest in number, followed by antibacterial (118), antiviral (110) and antihypertensive (79) drugs, in that order. For neurological disease, however, the numbers are much lower. There have been 12 anti-Parkinsonian drugs, 6 drugs for multiple sclerosis, and only 4 anti-Alzheimer drugs in the 30 years of research [5]. It is important to note that none of the so-called "anti-Alzheimer drugs" slow down or prevent neuronal death and the malfunction of the human brain [6]. Pharmacological treatments are only available for partial treatment of the symptoms [7]. No new AD drugs have been approved by the Food and Drug Administration (FDA) since 2003 [8]. This shows the severe lack of knowledge in neurodegenerative disease and demonstrates the requirement of further urgent research in this field. Although research has been progressing well in the field of neurosciences, drug development is falling well behind. The only advances since then have been the addition of a combination therapy using the previously approved drugs memantine hydrochloride (extended-release) and donepezil hydrochloride as Namzaric in 2014 [9]. Since many neurodegenerative diseases are multifactorial, disease combination therapy using a mixture of compounds or for example plant extracts, acting on several disease targets, could lead to promising results [10].

The numbers of drugs approved for other neurodegenerative diseases has not seen much of an increase over the last 8 years either. There was only a single new drug approved for amyotrophic lateral sclerosis (ALS) (Radicava, 2017) and HD (Austedo, 2017). A slightly higher number of drugs has been approved for PD (Duopa, 2015; Gocovri, 2017; Nuplazid, 2016; Rytary, 2015 and Xadago, 2017) [11]. For other neurodegenerative diseases, such as Prion diseases, e.g., Creutzfeldt-Jakob disease, or Spinocerebellar ataxia (SCA), e.g., SCA 1, 3 or 6, no drug therapies to retard their progress is currently available [12]. Treatment options for the latter diseases usually include physical or speech therapy or treatments aiming to alleviate the symptoms and most often requires an approach individualized for each patient. To find additional treatment options, current and new drug targets are under constant investigation. 


\subsection{Current and Future Drug Targets}

Current research has been focusing on a wide variety of different potential drug targets. In $\mathrm{AD}$ they are thought to be, for example, $N$-Methyl-D-aspartate (NMDA) receptor antagonists $[13,14]$, acetylcholinesterase inhibitors [14,15], antioxidants [16], radical scavengers [17], monoamine oxidase inhibitors [15] and $A \beta$ and tau aggregation inhibitors/dissolver [7]. In PD current treatment is mainly based on levodopa, a pre-stage of dopamine production, which can be converted into dopamine by the body to replenish the lost dopamine by the degeneration of dopaminergic neurons, which causes the disease. However, just like for most neurodegenerative diseases, this has helped to alleviate some of the symptoms associated with PD, but neither cures nor halts the disease in any way. Some of the current and future drug targets are summarized in Figure 1.

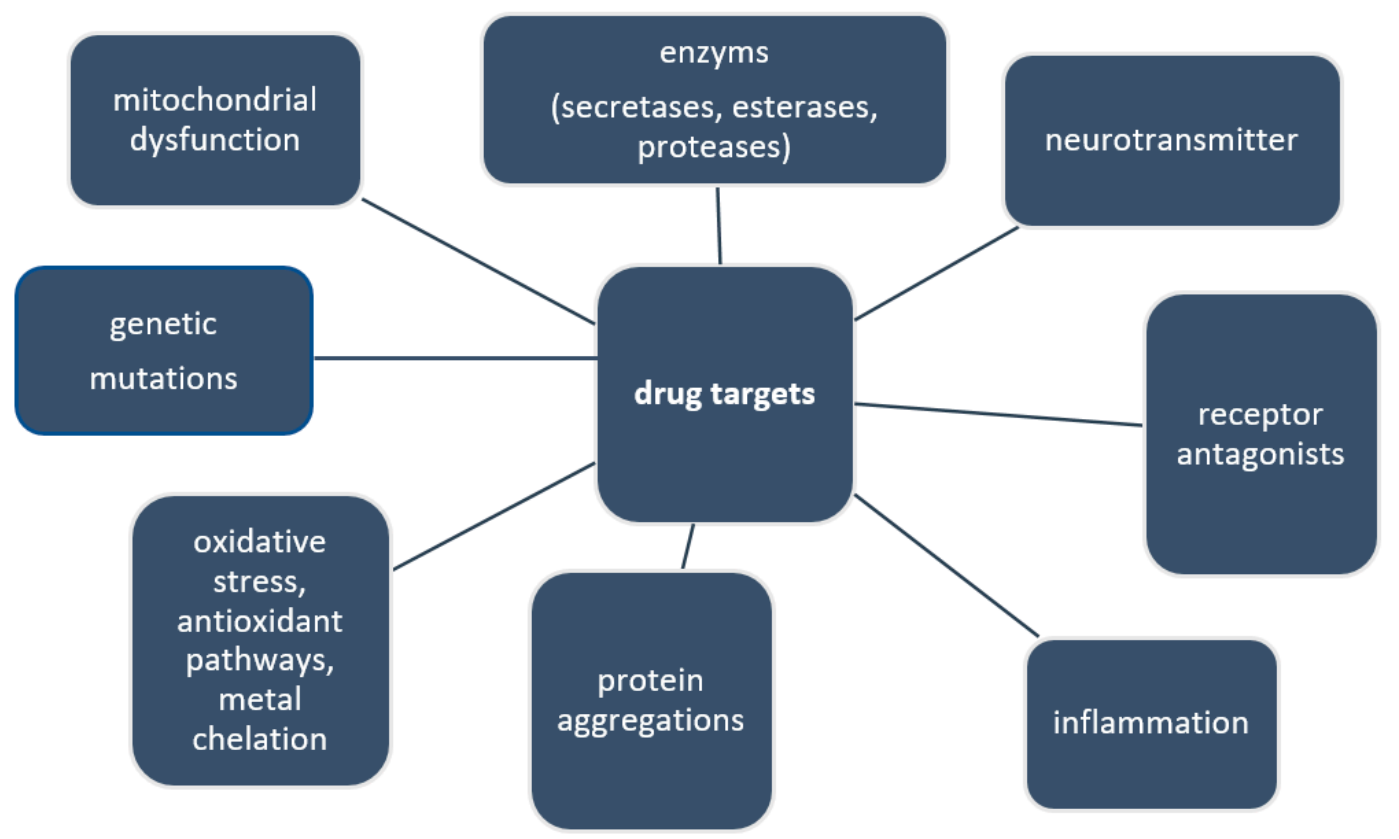

Figure 1. Examples of drug targets for neurodegeneration.

More recently, the inhibition of asparagine endopeptidase (AEP, a protease responsible for the cleavage of its substrates after asparagine residues) with small molecular inhibitors has been suggested as a potential target for $\mathrm{AD}$, because it is thought to play a role in the pathological processing of the amyloid precursor protein and tau proteins. If the role of AEP in AD brains can be further elucidated, its inhibition could be of importance for other age-related neurological disease such as PD, ALS and frontotemporal lobar degeneration (FTLD) [18].

Also, protein aggregations and their precursor stages have long been the target of several drug trials and significant research, for example AD, PD, and ALS, as well as HD and other polyglutamine disease (e.g., SCA) [19]. New pathways for restoring physiological protein conformations are still commonly sought after. One example being a recent study by Zunke et al. on the "Reversible Conformational Conversion of $\alpha$-Synuclein Toxic Assemblies by Glucosylceramide", where the reduction of glycosphingolipid diminished PD pathology in patient-derived neurons [20].

Other new ways of treatment, which have only become a potential option in the last few years, are stem cell gene therapies. Stem cells have the unique property of being self-renewing and can differentiate into specialized cell types. As a result, these have brought a significant amount of attention, especially in the field of neurodegeneration [21]. Studies on these systems have been conducted in vitro and in vivo, as well as in clinical trials in patients. A small Phase I/II and IIa clinical trial on the safety and clinical effects of mesenchymal stem cells secreting neurotrophic factor in patients with ALS found them to be safe and indicated possible clinical effects [22]. In another example, a small phase I 
study, gene therapy (ex vivo nerve growth factor (NGF) gene delivery) was used on 8 patients with mild AD. Participants had genetically modified autologous fibroblasts, modified to express human NGF, implanted into their forebrain. Follow up checks showed significant improvements in cognitive activities (Mini-Mental State Examination), suggesting the role of genetic modification [23].

Aging, one of the risk factors of many neurodegenerative diseases, was first associated with free radicals by Harman, in "Aging: A theory based on free radical and radiation chemistry" in 1956 [24]. Since then, reactive oxygen species (ROS) have been shown to be the cause of oxidative stress and have been associated with a range of neurological disorders such as AD, PD, HD and Pick's disease. It is assumed that reducing oxidative stress within the human body could at least be part of future treatment options, targeting multiple drug targets, as most neurodegenerative diseases have been associated with several different pathways involved in the disease development $[25,26]$.

Some of the compounds currently used for the treatment of neurodegenerative disease are of natural origin, such as Levodopa (L-DOPA), currently used for the treatment of PD. Originally, L-DOPA was isolated from seedlings of Vicia faba (1910-13) [27]. Similarly, Galantamine hydrobromide, a natural product from plants of the Galanthus genus, is used for the treatment of AD [28].

\subsection{Oxidative Stress}

Oxidative stress, a condition where the balance of reactive oxygen (ROS) and reactive nitrogen species (RNS) to antioxidants is in favor of ROS/RNS, is one of the causes associated with many neurodegenerative diseases. ROS, such as superoxide $\left(\mathrm{O}_{2}{ }^{\bullet-}\right)$, hydrogen peroxide $\left(\mathrm{H}_{2} \mathrm{O}_{2}\right)$ and hydroxyl radical $\left(\mathrm{OH}^{\bullet}\right)$, are generated during normal aerobic respiration of the cells. Other sources of oxidants include bacteria- or virus-infected cells that are destroyed by phagocytosis, generation of by-products in peroxisomes (lipid and fatty acid degradation), and by-products generated by cytochrome P450 [16].

It is well known that the production of ROS increases with age, while some of the endogenous defense mechanisms can decrease. If the balance between ROS and antioxidants is disturbed, the excessive amounts of ROS will damage cells by protein oxidation, DNA/RNA strand breakage, lipid peroxidation or the formation of advanced glycosylation end-products. These changes in the body with increased age lead to an aging phenotype related to neurodegenerative disease. However, it is important to remember that under normal conditions, a balance slightly on the pro-oxidant side is optimal for essential cell processes, such as cell signaling and redox regulation (Figure 2). Therefore, the antioxidant defense system should minimize the levels of harmful ROS, while enabling enough ROS to remain in the cell [29].

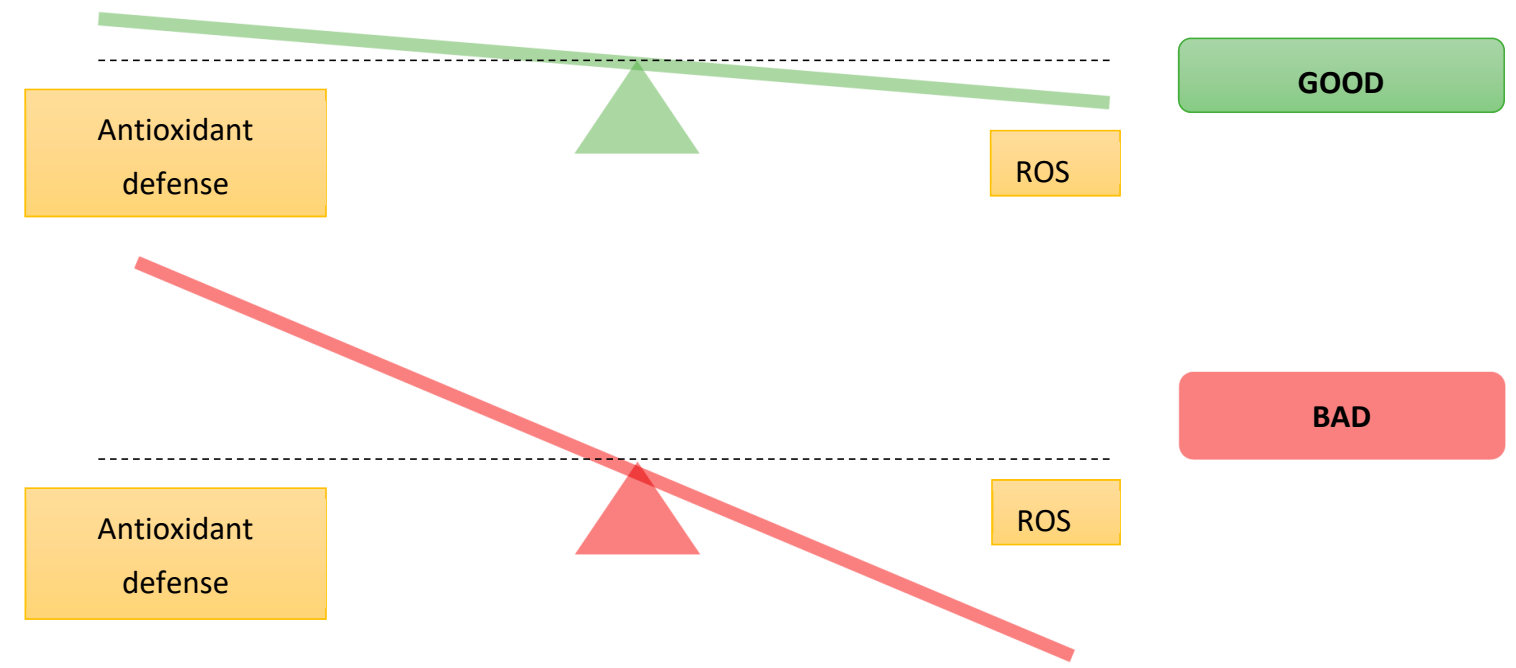

Figure 2. Difference between the normal and the disease state of oxidative stress balance adapted from Poljsak et al. [29]. 
Redox dysregulation can be caused by the ineffectiveness of the endogenous antioxidant system to handle an increase in the production of free radicals (e.g., disease, mitochondrial dysfunction, exposure to environmental factors) or because of a decreased effectiveness of the endogenous antioxidant system itself. These additional stress can cause damage to biological molecules that lead to rapid cell death, resulting in neurodegeneration, either by functional loss (ataxia) or sensory dysfunction (dementia) [30,31]. In addition, inflammation, protein aggregations (e.g., amyloid in AD), and excessive presence of metal ions such as iron $\left(\mathrm{Fe}^{2+}\right)$ and copper $\left(\mathrm{Cu}^{2+}\right)$ can cause oxidative stress (Figure 3).

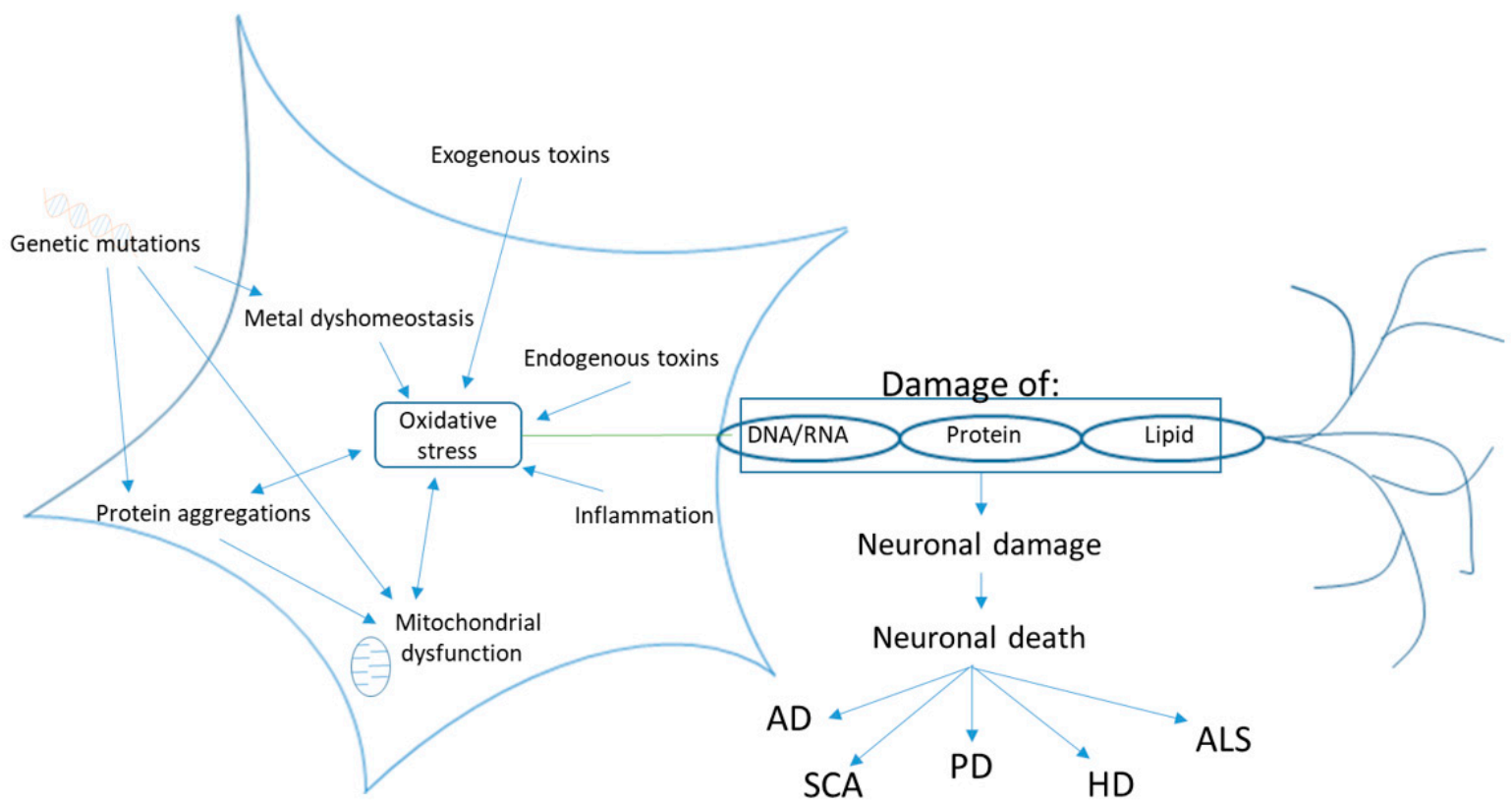

Figure 3. Causes of oxidative stress in neurodegeneration, AD-Alzheimer's disease, SCA—Spinocerebellar Ataxia, PD—Parkinsons disease, HD—Huntington's disease, ALS—Amyotrophic lateral sclerosis, adapted from $[32,33]$.

\subsection{Antioxidants to Counteract Oxidative Stress}

Generally, the human body has its own in-built antioxidant system (Figure 4), which ought to keep a balance between the production of ROS and the antioxidant defense system in our body. Keeping this biological equilibrium is especially important for neurons. Due to their very high oxygen consumption, long lifetime, and the additional formation of reactive nitrogen species and the prominent role of nitric oxide in the signaling processes, neuronal cells are even more susceptible to oxidative stress $[16,30]$. The natural human antioxidant system in our body can be divided in two groups, enzymatic and non-enzymatic [16] (Figure 4). 


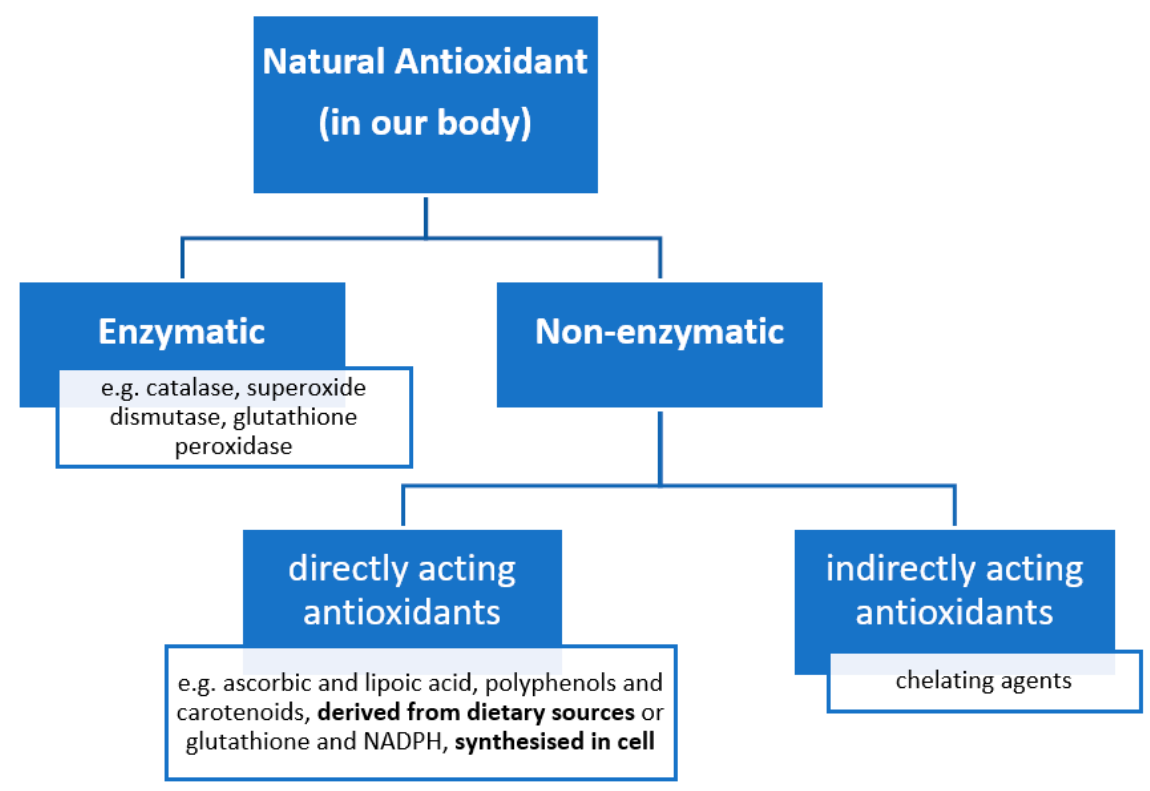

Figure 4. General natural Antioxidants categorized with examples, adapted from [16,34,35].

When the endogenous antioxidant system is not functioning well enough, an increased amount of external supply of antioxidants (exogenous antioxidants) could reduce the cumulative effect of oxidative stress [34], and hence prevent oxidative cell damage and neuron loss. Sources of available antioxidants can be either synthetic (chemically synthesized) or naturally occurring. A large variety of synthetic antioxidant compounds has previously been discussed by Augustyniak et al. [35] and Carocho and Ferreira [36]. However, these synthetic antioxidants are sometimes associated with a negative reputation, e.g., toxicity [36]. For this reason, in most antioxidant studies nowadays, compounds from natural sources are employed. One source of natural antioxidants is the human diet; plant products, especially, provide a good source of plant secondary metabolites, many of which have previously demonstrated positive antioxidant activities in vitro.

\subsection{Natural Product Drug Discovery}

In drug discovery pipelines, many plant natural products (single compounds isolated from natural sources) and/or plant extracts (containing various secondary metabolites) have shown antioxidant activity. Plant metabolites have provided inspiration for medicinal chemists and a platform for drug development processes for a very long time [37]. In the last two decades the use of plant metabolites in drug discovery has decreased, mainly due to the technical barriers for screening natural products in high-throughput assays for specific molecular targets, issues associated with the synthesis of natural compounds [38], advances in metagenomics, and the emergence of combinational chemistry [39]. However, more recently there has been a re-emergence of intense interest in plant metabolites. This is due to the advancement in improved fractionation and advanced NMR techniques for structural elucidation. This also includes profiling and isolation techniques such as HPLC-MS/MS, high-resolution Fourier-transform mass spectrometry and photo-diode arrays for metabolomics [38].

Biological activity detected in plants or plant extracts is mostly caused by plant secondary metabolites, which occur in plants at the higher level of structural diversity and number. They can fulfil a variety of different ecological roles in the plant, such as defense against herbivores, fungi, bacteria and viruses, as well as helping them compete for water, light and nutrients. In addition, they can also act as signaling compounds to attract pollinating and seed-dispersing animals, help to protect from external stress, such as UV light or physical harm, or have selected physiological functions [40]. According to Wink, secondary metabolites can be subdivided into two main categories, 
nitrogen-containing compounds and those without (Table 1). Examples of structures, pathways of secondary metabolite formation, and further details on each of the groups are provided by Wink [40].

Table 1. Secondary metabolite groupings.

\begin{tabular}{cc}
\hline Nitrogen-Containing & Without Nitrogen \\
\hline Alkaloids & Terpenes (Mono-, Sesqui-, Di-, Tri-, Tetraterpenes) \\
Non-protein amino acids & Steroids, saponins \\
Amines & Flavonoids, tannins \\
Cyanogenic glycosides & Phenylpropanoids, lignin, coumarins, lignans \\
Glucosinolates & Polyacetylenes, fatty acids, waxes \\
Alkamides & Polyketides \\
Lectins, peptides, polypeptides & Carbohydrates, organic acids \\
\hline
\end{tabular}

Although some secondary plant metabolites are thought to have disease-protecting properties in vivo, they are non-essential nutrients for humans. Phytochemicals from plants were shown to exhibit different biological activities, such as anti-inflammatory [41-44], anti-microbial [45,46], anti-carcinogenic $[46,47]$ and anti-diabetic properties $[48,49]$. Some of these are due to the regulation of several cellular molecular pathways [50]. Because of these varying properties, they are believed to have beneficial value for human health. Hence, the in vitro and in vivo effects of phytochemicals have shown intense interest as testified in the literature, including their ability to treat and prevent neurodegeneration $[28,45,48,51]$.

\section{In Vitro and In Vivo Antioxidant Activity of Plant Natural Products and Extracts}

To study neurodegenerative disease, and the potential use of natural plant products or plant extracts for their prevention or treatment, different model organisms, such as rodents (mice, rats), fruit fly (Drosophila melanogaster), zebrafish (Danio rerio) and nematodes (Caenorhabditis elegans), and unicellular organisms, such as yeast (Saccharomyces cerevisiae), have been studied [52]. Other options available for the understanding of neurodegeneration and the effect of treatment are cell-based studies. Recent developments in stem cell research have made it possible to generate induced pluripotent stem cells, which have the capacity to self-renew by dividing and to develop into all cells of the adult body from differentiated patient-derived cells in the laboratory [53]. Advancing this research even further has led to the creation of 3D models using human stem cells [52,54,55]. Examples of in vitro and in vivo studies using single natural product from plants as well as plant extracts are presented in Figure 5.

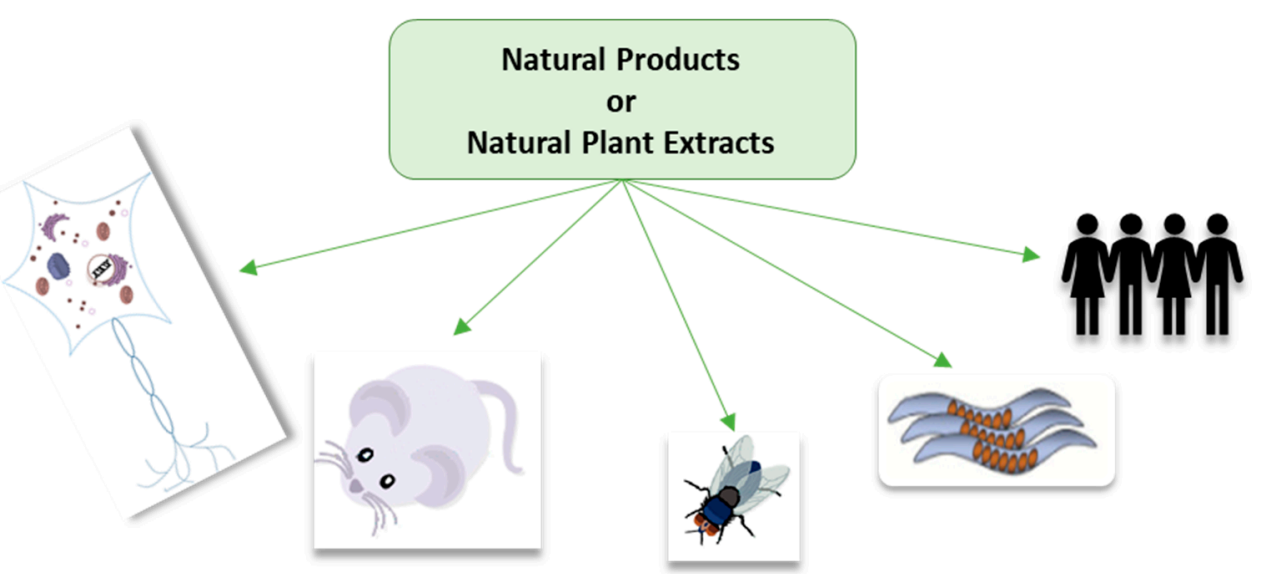

Figure 5. In vitro and in vivo models of neurodegenerative disease discussed in this review. 


\subsection{In Vitro Cell-Based Research}

When undertaking research on the effect of natural products in the field of neurodegeneration the best option for cell-based research is the use of primary neurons. Primary mammalian neurons can be derived from embryonic central nervous system tissue. However, the limitation of these is that once terminally differentiated into neurons, these cells will no longer propagate, and so the number of cells available for experiments is limited [56,57].

To overcome this issue, secondary cell lines, derived from neuronal tumors that have become immortalized can be used. The advantages of this are: (i) unlimited number of cells which grow easily in cell culture conditions; (ii) less variability; (iii) less challenging preparation and cell culture; (iv) approval from ethics committees is easier; and (v) facile transfection. There are cell lines currently being used for the search of potential treatment options from natural antioxidants, and these include neuroblastoma cell line SH-SY5Y, the human neuronally committed teratocarcinoma cell line NT2 or NTera, as well as the rat cell line PC12 derived from pheochromocytoma of the adrenal medulla and the HT22 mouse hippocampal neuronal cell line.

However, there are also disadvantages to using these neuron-like cell lines, such as more physiological differences to mature neurons, which make them less likely to show the same properties as matured neurons in vivo [57]. Depending on the field of interest, the right cell line/type needs to be chosen. Following all varieties of cell-related in vitro studies is considered to demonstrate the use of natural antioxidants in the field of neurodegeneration studies, using either whole plant extracts or single compounds found in plants.

In PC12 cells, Cheon et al. demonstrated the potential use of Korean mountain ash (Sorbus alnifolia) to protect dopaminergic neurons in the $\mathrm{MPP}^{+}$(1-methyl-4-phenylpyridinium) induced model of PD. In this study, the $\mathrm{MPP}^{+}$-mediated oxidative damage led to neurotoxicity. The viability of neurons was improved by pre-treatment with the methanol extract of Sorbus alnifolia for $2 \mathrm{~h}$ [58]. The same group also studied the effect of the extract in $\mathrm{MPP}^{+}$C. elegans models of $\mathrm{PD}$, which are detailed later. Previous chemical analysis undertaken on extracts of S. alniolia had shown the presence of the following phenolic compounds: protocatechuic acid, p-coumaric acid, caffeic acid, quercetin and most of all chlorogenic acid, with a total phenolic content (Folin-Ciocalteu method) of $76.6 \mathrm{mg}$ gallic acid equivalence (GAE) /g. The same study also showed the lack of toxicity from the extract $\left(\mathrm{IC}_{50}>500\right.$ $\mu \mathrm{g} / \mathrm{mL}$ ) on RAW 264.7 and HS-68 macrophage cells [59].

Extracts from Allium cepa (onion) have also received a lot of attention in recent years. In a paper by Lee et al. in 2016, Allium cepa extracts were found to protect primary cortical neuronal cells derived from mouse embryos from oxidative stress mediated by extracellular signal-regulated kinase (ERK) $1 / 2$ phosphorylation and mitogen-activated protein kinase (p38MAPK) dephosphorylation and inhibition of protein kinase $C$ $(\mathrm{PKC}-\varepsilon)$ [60]. In the same study, they verified that Allium cepa's main flavonoid component quercetin showed the same effect. Furthermore, the ability of the latter extracts to protect: (i) pUC19 plasmid DNA from oxidative stress induced by Fenton's reagent (ii) leukocyte DNA from $\mathrm{H}_{2} \mathrm{O}_{2}$-induced damage ( via comet assay) were verified by Fredotović et al. [61]. Of note several researchers had previously established the positive properties of onion extracts/quercetin in vivo [62-64].

Furthermore, the use of polyphenols displaying antioxidant properties has been widely studied and has shown promising effects in different diseased models. For example, Pate et al. [65] showed the potential of five flavonoids (flavone, apigenin, luteolin, kaempferol and quercetin) to attenuate $A \beta$ oligomer-induced neuronal responses associated with AD (Figure 6).

In that study, undifferentiated SH-SY5Y cells were induced with $A \beta_{1-42}$ oligomers, leading to increased cellular ROS and caspase activity. The tested flavonoids altered oligomer size distribution and conformation. In addition, they were able to attenuate the oligomer induced intracellular ROS and caspases activation (only for luteolin and quercetin, Figure 6) [65]. In a different paper, both luteolin and apigenin was shown to induce Nrf2-mediated gene expression, thought to be responsible for their anti-inflammatory effects [66]. The general in vitro and in vivo antioxidant properties of flavonoids have previously been reviewed by Procházková et al. [67]. 
<smiles>O=c1cc(-c2ccccc2)oc2ccccc12</smiles><smiles>O=c1c(O)c(-c2ccc(O)c(O)c2)oc2cc(O)cc(O)c12</smiles>

Figure 6. Structure of antioxidant flavonoids.

Other studies have looked into the properties of natural antioxidants that possess more than just antioxidant activity in vitro. [68]. For example, from a screened library of 84 antioxidants, 7 phenolics were selected which, apart from their antioxidant activity [67], also showed inhibition of kinase activity on leucine-rich repeat kinase-2 (LRRK2) substrates. Mutations in LRRK2 are known to cause familial PD; for example, the substitution of glycine for serine at amino acid position 2019 (G2019S mutation) is associated with increased kinase activity. Antioxidants that show inhibition of kinase LRKK2 substrates could turn out to be multi-target drugs for the treatment of PD.

G2019S mutation-transfected SK-N-SH and cortical neurons, for example, showed increased viability when treated with piceatannol (phenolic found in grapes, passion fruit, white tea and Japanese knot [69]), thymoquinone (quinone active metabolite in Nigella sativa (black cumin [70]) and esculetin (coumarin found in bark of Cortex fraxini (traditional Chinese medicinal herb) [71]) [68] Figure 7. Compounds with both antioxidant and kinase inhibitory properties provide an added advantage when compared with single-target compounds, since they can hit two or more targets at the same time.

Vanillin (4-hydroxy-3methoxybenzaldehyde, Figure 8), a phenolic compound found in the beans and pods of tropical vanilla orchids (V. planifolia, V.tahitensis and V. pompon) currently used as food or beverage flavoring or in cosmetics and household products, has been shown to inhibit peroxynitrite-mediated reactions [72].

Although not exhibiting high DPPH scavenging activity, it does show activity in the ABTS ${ }^{+}$-scavenging and the ORAC assays [73], and it protects plasmid DNA from AAPH-induced DNA strand breakage [74]. In an unrelated neurodegeneration study, vanillin was also found to be an anti-inflammatory agent [75]. Considering these positive characteristics, Dhanalakshmi et al. [76] tested Vanillin's potential to protect SH-SY5Y cells from rotenone-induced PD-like neurotoxicity. Undifferentiated cells were pre-treated with vanillin $(2 \mathrm{~h})$ and then co-treated with rotenone $(24 \mathrm{~h})$. Vanillin protected cells from rotenone-induced cell death, ROS generation, and changes in membrane potential, as well as apoptotic changes in cellular morphology and protein expression [76]. 
<smiles>CC1=CC(=O)C(C(C)C)=CC1=O</smiles>

Figure 7. Phenolics from plants.<smiles>COc1cc(C=O)ccc1O</smiles>

Figure 8. Structure of vanillin.

\subsection{In Vivo Drosophila Models}

Much research has been conducted on natural products displaying antioxidant properties and neurodegeneration on in vivo Drosophila models. Drosophila have several advantages over mammalian models; for example, their small size and low maintenance costs, easy genetic manipulation, short life cycle, large number of progenies, exhibition of complex behaviors, and less stringent ethical concerns. A review by McGurk et al. [77] summarizes the use of Drosophila in neurodegenerative disease research.

An interesting paper by Jahromi et al. [78] utilized drosophila PD models (missense A30P mutations and A53T $\alpha$-synuclein) to test the biological activity of swallowroot (Decalepis hamiltonii). Transgenic flies fed with the aqueous Decalepis hamiltonii extracts ( 0.1 and $0.5 \%)$ showed significantly improved climbing ability as well as circadian rhythm of locomotor activity. These motor improvements were associated with reduced ROS and lipid peroxidation, and with increases in CAT and SOD activity. Similar positive results were obtained with the deteriorated phenotype after treatment with paraquat. However, an improvement in climbing ability of the transgenic flies, as well as protection from mortality, was observed for both models at $0.1 \%$ and $0.5 \%$ treatment concentrations. Preliminary chemical analysis of Decalepis hamiltonii revealed the presence of ellagic acid (Figure 9), a well-known antioxidant plant secondary metabolite. Both the extracts and ellagic acid on its own showed radical scavenging activity together with metal-chelating activity in vitro [79,80]. Ellagic acid also exhibits cyto-protective activity in EAT cells following stress induction with hexachlorocyclohexane $(\mathrm{HCH})$, cumene hydroperoxide (CHP) and carbon tetrachloride $\left(\mathrm{CCl}_{4}\right)$. In addition, xenobiotic-induced ROS production and lipid peroxidation was inhibited, together with the prevention of GSH depletion [80].<smiles></smiles>

Figure 9. Structure of ellagic acid. 
Another recent study [81] looked into the activity of Peacocks tail (brown algae; Padina pavonica) and barbary fig (Opuntia ficus-indica), which had previously been shown to exhibit very strong antioxidant activity [82,83], and had provided ameliorating effects in neurodegenerative disease models in Drosophila (AD, PD) and yeast (AD). Both extracts were able to improve the survival and mobility in AD models. The observed improvements were found for two different disease models, whereas Padina pavonica extracts improved a pan-neuronal expression of a double dose of A $\beta 42$ (late-onset AD model), Opuntia ficus-indica showed positive effects in a model of early-onset AD (flies expressing the Arctic $\mathrm{A} \beta 42$ ). Furthermore, both extracts improved survival of $\alpha$-syn ${ }^{\mathrm{A} 53 \mathrm{~T}}$ expressing PD model and attenuated $\mathrm{A} \beta 42$ and $\alpha$-syn oligomer toxicity while demonstrating anti-amyloidogenic potential against both proteins in vitro [81].

While Angeles et al. [68] found increased viability when treating G2019s transfected SK-N-SH and cortical neurons with piceatannol, thymoquinone and esculetin (see above), they also tested these three compounds in G2019S-expressing transgenic flies. Their results showed that these kinase inhibitors also provide protection from loss of dopaminergic neurons, suggesting amelioration of LRRK2 induced toxicity. In addition, the flies' motor abilities (climbing), impaired in G2019S animals, were improved with piceatannlo and thymoquinone treatment. Both esculetin and thymoquinine also reversed the decrease in life expectancy induced by the mutation.

\subsection{In Vivo C. elegans Models}

In addition to Drosophila, the nematode C. elegans is a well-established model for neurodegenerative disease research. A review by Alexander et al. provides a good overview on the different $C$. elegans models available for AD, PD, ALS and others with details on the advantages and limitations of these models [84].

A further review on "Using C. elegans to discover therapeutic compounds for aging-associated neurodegenerative diseases" by Chen et al. [85] goes into further depth in using C. elegans models in the search for treatments for neurodegeneration and lists compounds which have shown beneficial effects, including secondary metabolites such as caffeine, curcumin, epigallocatechin, ferulic acid, resveratrol and valproic acid (Figure 10).

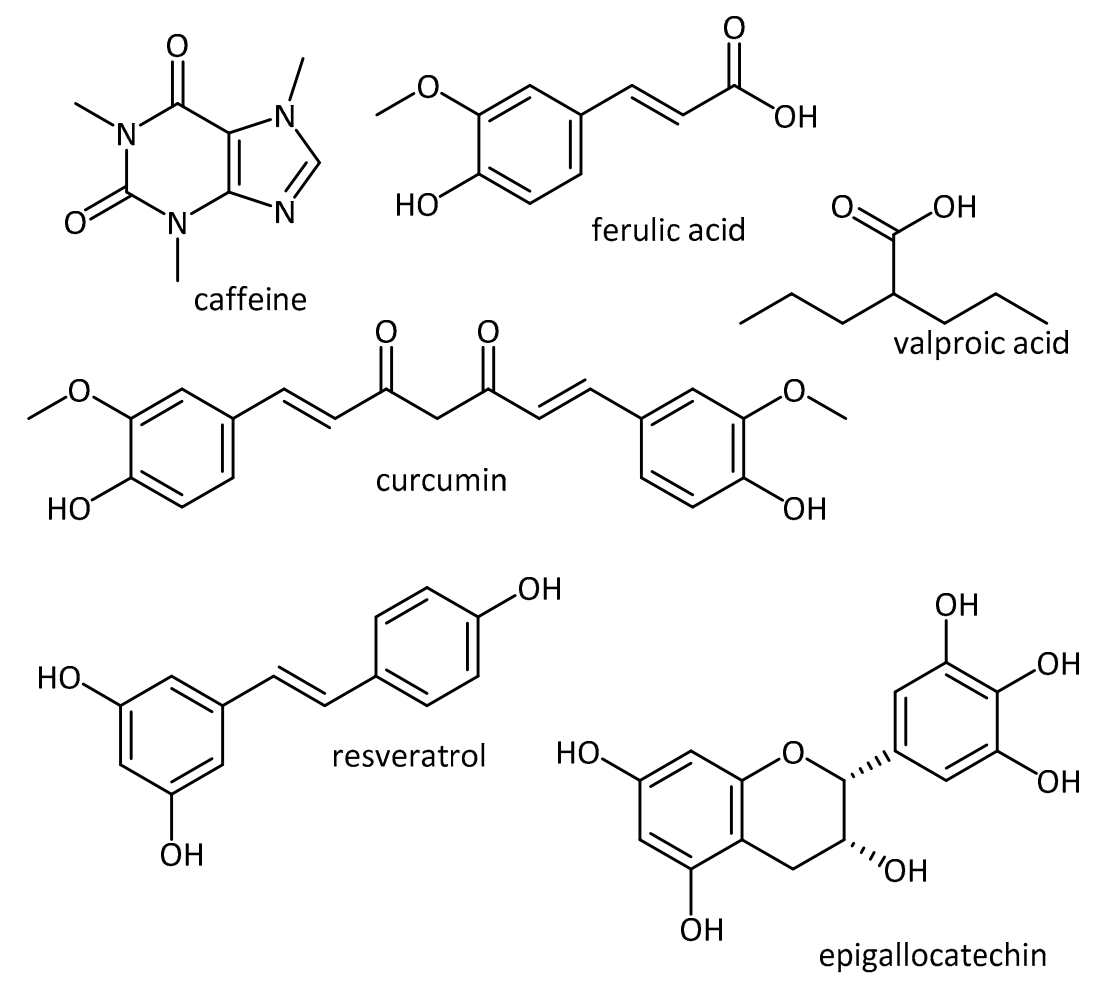

Figure 10. Natural products used in the study of aging-associated neurodegenerative diseases. 
Both natural products isolated from plants and plant extracts containing a vast number of active ingredients have been used and have shown positive effects in various neurodegenerative disease models. Methanol extracts of tea seed pomace from Camellia tenuifolia (oil-tea tree), for example, decreased intracellular ROS and prolonged lifespan and survival nder oxidative stress in Bristol $\mathrm{N} 2$ (wild type). In an $\mathrm{AD}$ model, the extract was able to reduce $\beta$-amyloid (A $\beta$ ) toxicity in transgenic $C$. elegans expressing human $A \beta$ (strain CL4167). Its radical scavenging activity and phenolic content were verified using the DPPH and the Folin-Ciocalteu method, respectively. Fractionation demonstrated that one fraction was particularly active. Semi-preparative HPLC analysis was used to determine the constituents present in this fraction as kaempferol derivatives kaempferol 3-O-(2"-glucopyranosyl)- rutinoside and kaempferol 3-O-(2"-xylopyranosyl)-rutinoside, which, when tested in the oxidative stress-induced survival assay, showed a significant increase of protection [86].

In a PD model induced by the treatment of $C$. elegans with $\mathrm{MPP}^{+}$, the extract of Korean mountain ash (Sorbus alnifolia) restored viability of the worms after 30 min pre-treatment prior to $\mathrm{MPP}^{+}$addition. Using the transgenic strain BZ555 ((egIs1, Pdat-1::GFP) expressing GFP in the 8 dopaminergic (DAergic) neuron of hermaphrodite C. elegans, observations also showed that the extract protected DAergic neurons from $\mathrm{MPP}^{+}$(environmental) induced neuronal loss [58]. The same was true for the genetic PD model UA57 (Pdat-1::GFP and Pdat-1::CAT-2), where the overexpression of tyrosine hydroxylase led to DAergic neurodegeneration. Extract concentration of $250 \mu \mathrm{g} / \mathrm{mL}$ showed the best neuroprotection in both models. The extracts, however, failed to prevent aggregation of $\alpha$-synuclein in a transgenic strain (NL5901). Further studies into the phenotypical induced behavioral dysfunction induced by MPP (basal slowing response) demonstrated the extracts' activity in reducing the phenotypical dysfunction. In addition, the extract increases the overall life span in N2 (wild type) animals [58].

In non-mammalian model organisms, the use of both pure natural products and extracts is common. There is also increasing evidence that using either single compounds or a mixture of compounds (mix of individual compounds or extracts) acting on several molecular targets or pathways could be a more effective therapeutic strategy than using natural products. Drug trials like this can be more rapidly undertaken in C. elegans or Drosophila models compared to rodents. Advanced molecular methods such as RNAi and CRISPR have made it easier to create models of neurodegenerative disease more rapidly and accurately [85]. Single copies of mutant genes found in patients can now be delivered precisely to appropriate locations in the model genome, without long-lasting gene editing or crossing. This might lead to faster and better understanding of disease mechanisms and potential ways of treatment.

In our own research, using antioxidant rapeseed (Brassica napus) pomace/cake extracts [87,88], we showed neuroprotective properties in a C. elegans model of SCA3 or Machado-Joseph disease. Further investigation also found positive effects in different PD C. elegans models. Currently, we are studying the mechanism of activation of the antioxidant pathways after treatment with RSP extract (unpublished).

\subsection{In Vivo Rodent Models}

Cellular and invertebrate models can yield much useful information. However, due to their simplistic nature, detailed information/mechanisms from these models can be limited when it comes to translational research [89]. In the field of neurodegenerative research, rodent models are still important for pre-clinical models, which we cannot evade when searching treatments for neurological disorders using either natural or synthetic entities. Several reviews have reported on the background of the different rodent models available for modeling neurodegenerative diseases, including both genetic and potential pharmacologic models [90-92]. Rodent models, just like non-mammalian models, come with several advantages and disadvantages. Some of the advantages are the closer genetic similarity to humans and their higher complexity compared to, e.g., C. elegans and Drosophila melanogaster or in vitro cell models [93]. Although translation of research from rodent models to human trials on disease modifying therapies remains an issue [90], it is worth mentioning that the number of papers 
(between 30-40\% from 1975 to 2015) using rodent models still outweighs the number of any other publications in neuroscience, as presented by Keifer and Summers [93].

In a recent study by Ali et al. [94], an APP/PS1 (AD) mouse model was employed, containing human transgenes for both amyloid precursor protein (APP) and the L166P mutation of presenilin (PS-1) [95]. In this model, anthocyanins (Figure 11) extracted from Korean black soybeans (methanol 95\% extract, purified in a XAD-7 column) was shown to regulate the PI3K/Akt/GSK3 pathway, activated the downstream endogenous anti-oxidant $\mathrm{Nrf2}$ transcription factor and its target genes HO-1 and GCLM. By doing so, the amyloid $\beta$ oligomer (A $\beta O)$-induced elevation of ROS was reduced and neurodegeneration via a PI3K/Akt/Nrf2-dependent pathway was prevented. In this study, anthocyanins improve memory-related pre- and postsynaptic markers and cognitive functions in APP/PS1 mice. Similar results were also found in their A $\beta O$-exposed HT22 mouse hippocampal neuronal cells [94]. Major anthocyanins in black soybean have previously been identified as delphinidin-3-O- $\beta$-D-glucoside, cyanidin-3-O- $\beta$-D-glucoside and petunidin-3-O- $\beta$-D-glucoside [96].<smiles>OC[C@H]1O[C@@H](Oc2c[o+]c3cc(O)c(-c4ccc(O)c(O)c4)[o+]c3c2)[C@H](O)[C@@H](O)[C@H]1O</smiles>

delphinidin-3-O-beta-D-glucoside

cyanidin-3-O-beta-D-glucoside

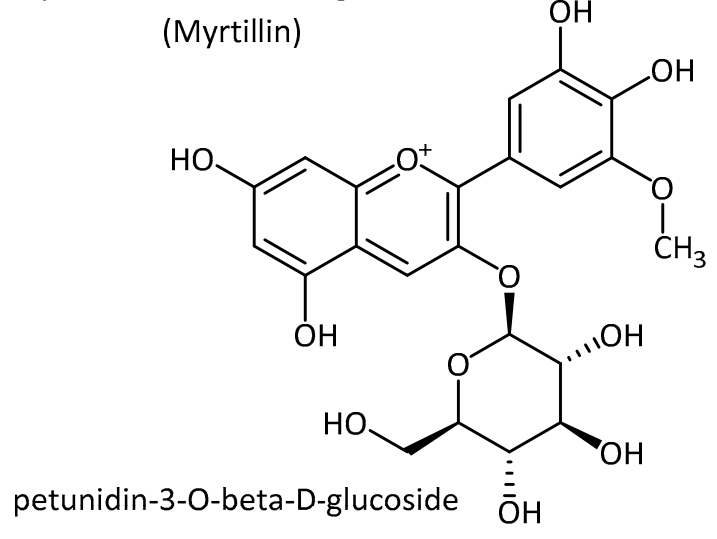

Figure 11. Structure of anthocyanins.

In vitro and in vivo data collected in the study by Ali et al. [94] showed that anthocyanins and secondary metabolites act as potential antioxidants by activating antioxidant pathways, and hence could be beneficial for the prevention of age-related neurological disorders, e.g., AD.

Another well-researched secondary metabolite, known to have antioxidant activity in vitro [97], is resveratrol (Figure 12). Several studies in mice have suggested its use for the treatment or prevention of neurodegenerative disease. For example, in a SCA-3 (Machado-Joseph disease, MJD) mouse model, resveratrol activates the histone deacetylase enzyme SIRT1 pathway, showing improvement in motor behavior when treating animals at a post-symptomatic stage of disease development. In that study, the resveratrol data were compared to caloric restriction, which also decreases motor deficits via activation of SIRT1 [98]. The effect of resveratrol has previously been recorded in different neurodegenerative disease models (AD, HD, ALS, PD), both in vitro and in vivo [99]. 
<smiles>Oc1ccc(/C=C/c2cc(O)cc(O)c2)cc1</smiles>

Figure 12. Structure of resveratrol.

Single compounds do not always show the same positive effect when moving from in vitro to in vivo environments or to clinical trials. This could be due to the bioavailability of natural products in an in vivo setting. A newer trend in the search to treat or prevent neurodegenerative disorders is combination therapy. New assumptions are that a combination of different compounds, as seen in many extracts, or a mixture of natural products, could lead to better results. Mori et al. [100], for example, used a combination treatment of octyl gallate (antioxidant activity [101]) and ferulic acid (neuroprotective [102] and in vitro antioxidant activity [103] Figure 13) in a mouse model of AD (PSAPP transgenic mouse model of cerebral amyloidosis).<smiles>CCCCCCCCOC(=O)c1cc(O)c(O)c(O)c1</smiles>

Figure 13. Natural products used in combination treatment.

The results were compared to single compound treatment, and the combination treatment showed significantly better results than the single compounds. The combination treatment led to improved cognitive functions, reduced level of $\beta$-amyloid deposits, and amyloid $\beta$-protein abundance, as well as attenuated neuroinflammation, oxidative stress and synaptotoxicity [100]. Ferulic acid has not only shown success in mouse, but also in rat models of neurodegeneration (see below).

In a rotenone-induced rat model of PD, ferulic acid (Figure 14), a common phenolic acid in many plants, rescued dopamine neurons in the substantia nigra pars compacta area and nerve terminals in the striatum from the rotenone insult. In addition, ferulic acid restored antioxidant enzymes (SOD and CAT), prevented glutathione depletion levels, and inhibited lipid peroxidation (MDA level). Inflammatory mediators and pro-inflammatory cytokines were reduced. The observed positive effects are thought to be mediated by the phenolic acid's antioxidant and anti-inflammatory properties [104].<smiles>COc1cc(/C=C/C(=O)O)ccc1O</smiles>

Figure 14. Structure of (A) sinapic acid and (B) ferulic acid. 
In comparison, in a 6-OHDA-induced model of PD (unilateral intrastriatal), Wistar rats were pre-treated with sinapic acid (Figure 14), showed improved turning behavior and the prevention of neuron loss in the substantia nigra pars compacta so common for PD. In addition, sinapic acid reduced the levels of MDA and nitrite and lowered iron reactivity. These results led to the assumption that neuroprotection is at least partially due to antioxidant activity [105] and sinapic acid's potential to lower iron levels in vivo [106].

In general, it would appear that the number of studies related to plant extracts decreases when moving from in vivo models such as C. elegans and Drosophila to mammalian models such as mice and rats. In Kaur et al., rice bran extracts were used to study their beneficial effect in 3-nitropropionic acid induced experimental HD rats. In that study, both the hexane and ethanol extracts of rice bran were able to attenuate the 3-nitropropionic acid induced behavioural, biochemical, neuro-inflammatory and neurochemical changes, suggesting the potential use of rice bran as adjuvant or prophylactic therapy.

More often, pure natural products are tested, for example sulforaphane, an isothiocyanate (Figure 15) known to originate from the breakdown of glucoraphanin, a glucosinolate present in many cruciferous vegetables. In an AD mouse model (induced by the combined administration of D-galactose and aluminum), sulforaphane was able to improve neurobehavioral deficits and protect mice brains from $A \beta$ deposits and peroxidation [107]. Similar positive results for sulforaphane were found in other rodent models of AD [108], HD [109] and PD [110]. Sulforaphane is a well-researched Nrf2 transcription factor activator, and hence it has received a lot of attention in related non-animal studies [111-113].

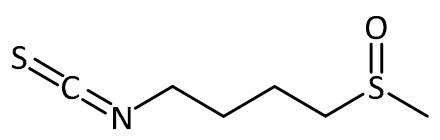

Figure 15. Structure of sulforaphane.

Another isothiocyanate 4-( $\alpha$-L-Rhamnosyloxy)-benzyl, present in Moringa oleifera (drumstick tree) seeds, after breakdown of glucomoringin by myrosinase, was able to delay the disease phenotype of a $\mathrm{SOD} 1{ }^{\mathrm{G} 93 \mathrm{~A}}$ rat transgenic model of ALS. Again, natural products were used instead of using the plant material itself or extracts obtained from it.

Below, Table 2 highlights a few of the natural antioxidants that have shown beneficial effects in in vitro and in vivo animal models, including several examples discussed above, as well as additional recent studies. 
Table 2. Pre-clinical effect of natural antioxidants in vitro and in vivo.

\begin{tabular}{|c|c|c|c|c|}
\hline $\begin{array}{l}\text { In Vitro/ } \\
\text { In Vivo }\end{array}$ & Origin of antioxidant/s & Model system & Condition & Molecular Outcome \\
\hline \multirow{7}{*}{ In vitro } & Korean mountain ash (Sorbus alnifolia) & PC12 cells & $\mathrm{PD}$ & \multirow{7}{*}{$\begin{array}{l}\text { - restored } \mathrm{MPP}^{+} \text {-induced loss of viability [58] } \\
\text { - protection of cells mediated through ERK1/2 phosphorylation and } \\
\text { p38MAPK dephosphorylation and inhibition of PKC- } \varepsilon \text { [60] } \\
\text { - attenuated rotenone induced mitochondrial dysfunction, ROS generation, } \\
\text { oxidative stress, and apoptosis [76] } \\
\text { - flavonoids altered oligomer size distribution and conformation and were } \\
\text { able to attenuate the oligomer induced intracellular ROS and caspases } \\
\text { activation (only for luteolin and quercetin) [65] } \\
\text { - ameliorate MPTP-induced neurotoxicity [114] } \\
\text { - decreased reactive oxygen species (ROS), mutant ataxin-3 and apoptosis } \\
\text { and increased autophagy in pro-oxidant tert-butyl hydroperoxide } \\
\text { (tBH)-treated cells [115] } \\
\text { - increased viability through multi-target approach of antioxidant and kinase } \\
\text { inhibitory properties (LRRK2 model of PD) [68] }\end{array}$} \\
\hline & Onion (Allium cepa)/ quercetin & $\begin{array}{l}\text { primary cortical neurons derived } \\
\text { from mouse embryos }\end{array}$ & Oxidative stress & \\
\hline & Vanillin & (1) & Neurodegeneration in general & \\
\hline & Flavonoids & & $\mathrm{AD}$ & \\
\hline & Pomegranate Juice Extracts & Primary human neurons & $\mathrm{PD}$ & \\
\hline & Caffeic Acid and Resveratrol & SK-N-SH-MJD78 & $\mathrm{MJD} / \mathrm{SCA} 3$ & \\
\hline & Piceatannol, thymoquinone, esculetin & SK-N-SH -G2019S & PD & \\
\hline \multirow{7}{*}{ In vivo } & Korean mountain ash (Sorbus alnifolia) & \multirow{4}{*}{ C. elegans } & $\mathrm{PD}$ & \multirow{4}{*}{$\begin{array}{l}\text { - protection against chemically and genetically induced DAergic } \\
\text { neurodegeneration, increased food-sensing functions and prolonged average } \\
\text { lifespan [58] } \\
\text { - decreased intracellular reactive oxygen species, prolonged lifespan and } \\
\text { reduced amyloid- } \beta(\mathrm{A} \beta) \text { toxicity in transgenic C. elegans expressing human } \\
\mathrm{A} \beta[86] \\
\text { - decreased the accumulation of } \alpha \text {-synulein and protection from 6-OHDA } \\
\text { induced dopaminergic neurodegeneration, improved movement, potentially } \\
\text { associated with up-regulation of the stress response genes, sod-3 and } \\
\text { skn-1 [116] } \\
\text { - decreased a-syn accumulation in the transgenic C. elegans model and } \\
\text { reduction of 6-OHDA-induced dopaminergic neuron degeneration, } \\
\text { improved food-sensing behavioral and reversed life-span decreases in a } \\
\text { pharmacological C. elegans model [117] }\end{array}$} \\
\hline & Tea Seed Pomace (Camellia tenuifolia) & & $\mathrm{AD}$, aging & \\
\hline & Extract from red seaweed (Chondrus crispus) & & $\mathrm{PD}$ & \\
\hline & Betulin (e.g., from outer bark of birch trees) & & $\mathrm{PD}$ & \\
\hline & Caffeic Acid and Resveratrol & \multirow[t]{3}{*}{ Drosophila melanogaster } & $\mathrm{MJD} / \mathrm{SCA} 3$ & \multirow{3}{*}{$\begin{array}{l}\text { - improved survival and locomotor activity and decreased mutant } \\
\text { ataxin-3 and ROS levels in tBH-treated SCA3 Drosophila [115] } \\
\text { - significantly improved climbing ability and circadian rhythm of locomotor } \\
\text { activity, reduced levels of ROS and LPO and enhanced catalase (CAT) and } \\
\text { superoxide dismutase (SOD) activity [78] } \\
\text { - improvement of the survival and mobility of AD models, Padina pavonica } \\
\text { extracts improved a pan-neuronal expression of a double dose of A } \beta 42 \\
\text { (late-onset AD model), Opuntia ficus-indica showed positive effects in a } \\
\text { model of early onset AD (flies expressing the Arctic A } \beta 42 \text { ) }\end{array}$} \\
\hline & $\begin{array}{l}\text { Aqueous root extract from swallowroot (Decalepis } \\
\text { Hamiltonii), ellagic acid }\end{array}$ & & PD & \\
\hline & $\begin{array}{l}\text { Peacocks tail (brown algae; Padina pavonica) and } \\
\text { barbary fig (Opuntia ficus-indica) }\end{array}$ & & $\mathrm{AD}$ & \\
\hline
\end{tabular}


Table 2. Cont

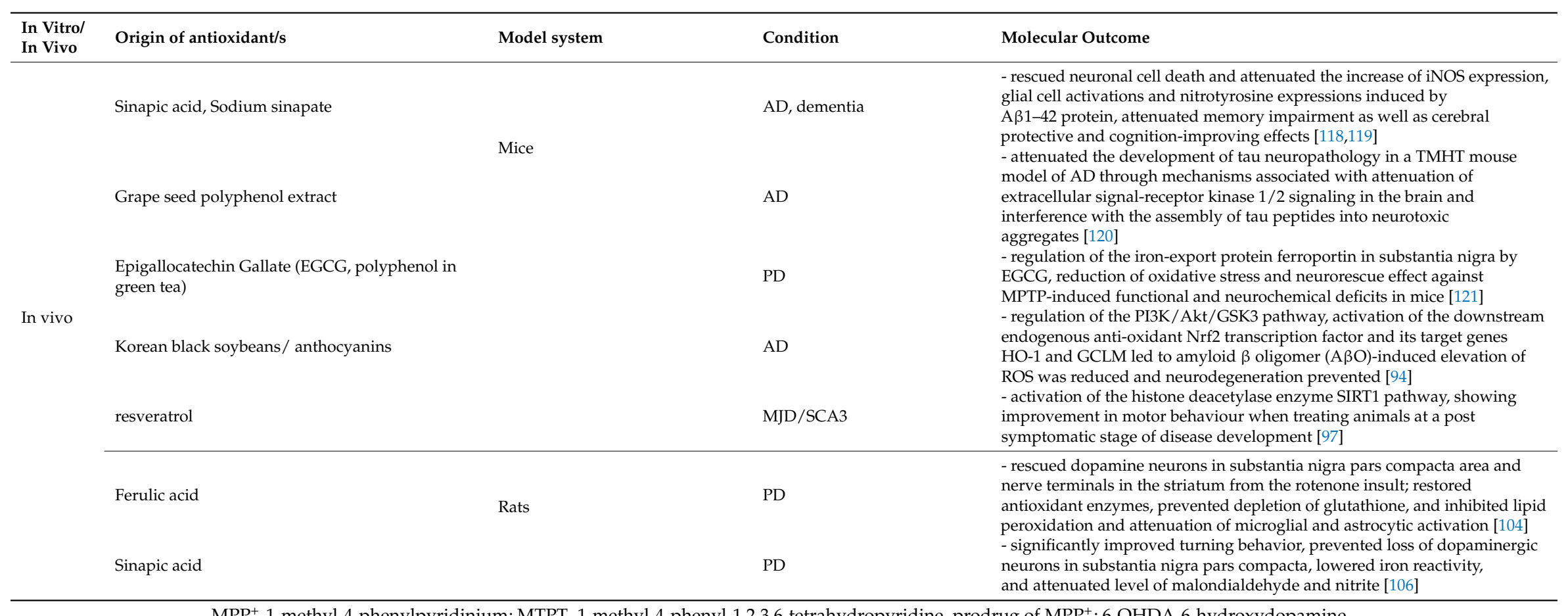

$\mathrm{MPP}^{+}$-1-methyl-4-phenylpyridinium; MTPT- 1-methyl-4-phenyl-1,2,3,6-tetrahydropyridine, prodrug of MPP${ }^{+}$; 6-OHDA-6-hydroxydopamine. 


\section{Clinical Trials: Positive vs. Negative Outcomes}

The interest in using natural products in clinical trials has recently been on the increase. In 2017, the National Centre for Complementary and Integrative Health (NCCIH) introduced new funding opportunities for natural product clinical trials through a webinar [122].

Caffeine (Figure 16) is a well-known secondary plant metabolite with good antioxidant activity and is under constant research for its health benefits. Caffeine has already shown promising results in both in vitro and in vivo animal models of neurodegenerative disease. In addition, different clinical trials have been undertaken using caffeine as a therapy for PD. Initial studies (2010/2011, Phase 2, estimated enrolment 28 participants) on the tolerability of caffeine, as well as secondary outcome measures such as Epworth Sleepiness Scale, Unified PD rating scale, timed up and go, and others were analyzed (NCT01190735). No record of the results from this study are available; therefore, the outcome remains unclear. Under the same investigator (Ronald B. Postuma, McGill University Health Center) a further Phase III study took place using caffeine as well as a placebo control with 119 participants, randomized and double blinded (NCT01738178). The results from that study concluded that caffeine did not show clinically relevant improvements in the motor manifestations of PD. Links between caffeine and a lower risk of developing PD do not seem to be explained by symptomatic effects [123]. Unfortunately, no molecular measurements of protein aggregations or changes in antioxidant levels in the patients were undertaken.<smiles>Cn1c(=O)c2c(ncn2C)n(C)c1=O</smiles>

Figure 16. Structure of caffeine.

Another natural product widely referred to its antioxidant activity is huperzine A (Figure 17), a cholinesterase inhibitor derived from the Chinese herb Huperzia serrata. In addition to its acetylcholinesterase inhibition activity, huperzine A has been shown to reduce the amounts of soluble and insoluble $\beta$ amyloid levels and levels of amyloid plaques in AD mice. Mice on a high-iron diet, however, showed no reduction [124]. This and other "non-cholinergic" effects seen by the treatment with huperzine A are documented by Qian and Ke [125]. In a phase II trial (2004-2007, NCT00083590) investigating huperzine A, with 210 patients (177 completions) diagnosed with probable $\mathrm{AD}$, with doses of $200 \mu \mathrm{g}$ twice daily (BID- bis in die, Latin), no significant changes in the AD Assessment Scale cognitive subscale (ADAS-Cog) were seen after 16 weeks. However, secondary analysis at $400 \mu \mathrm{g}$ concentration of BID showed improvements at 11 and 16 weeks, suggesting higher doses might improve cognitive functions [126]. Another review by Yang et al. took a further 20 randomized clinical trials into review, where the potential use of huperzine $\mathrm{A}$ in the improvement of cognitive function, daily living activity and global clinical assessment for AD patients was analyzed. However, the conclusion also suggested caution with the results, as some of the studies showed poor methodological quality and the suggestion was made for more rigorous clinical trials to support clinical use of huperizine A. An issue with all the trials included in this review ( $n=20$ published between 1995 and 2012) is the fact that none of them used concentrations higher than $300 \mu \mathrm{g}$ BID. Nevertheless, as shown in the previous study, only concentrations above $200 \mu \mathrm{g}$ BID showed promising results. The question is why so many clinical trials have been undertaken at concentrations below the effective concentration. 


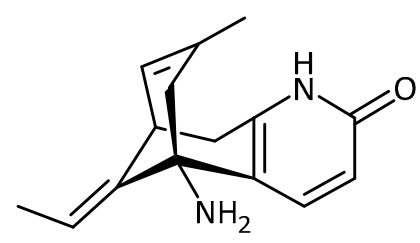

Figure 17. Structure of huperzine A.

Due to a lack of significant clinical improvements using single antioxidant compounds, clinical trials have started to move away from single compounds and are starting to look into the use of plant extracts. For example, one clinical trial, started in 2014 (ClinicalTrials.gov Identifier: NCT02033941), studied the effect of Meganatural-Az Grapeseed Extract in a randomized placebo-controlled phase II trial. The results from this study were expected in September 2018, but no publications on the outcomes were found by the time of submission of this review. The aims of this study are to determine the safety and pharmacokinetics of grapeseed extracts in participants with AD. In addition, clinical and biomarker indices will be assessed to determine therapeutic efficacy. However, the low number of participants (20) might make it difficult to see significant results. On the other hand, it will hopefully be able to provide necessary human data to direct further studies using the extract with a higher number of subjects.

Miroddi et al. reviewed a total of eight clinical trials using two Salvia species, known as "common sage" and Spanish sage (S. officinalis L. and S. lavandulaefolia L., respectively), to assess their pharmacological properties on memory and cognitive impairment in AD. All those trials were based on whole herbal extracts. Trials conducted on Salvinorina-A, an isolated compound from a different species of the Salvia genus, were not included. The conclusion from this review revealed several clinical trials on both Salvia species to show improved cognitive performance in healthy subjects and patients with dementia/cognitive impairment. No serious adverse effects were observed with treatment when compared to a placebo control. However, one issue highlighted in this review was the inconsistent preparation of herbal products and a lack of details on the products used [127]. Such a lack in quality control for the preparation of natural extracts is worrying and could explain why clinical trials are more often done on a single compound with a specific dose. When undertaking clinical trials on extracts, their production, chemical composition and the origin of the plant material must be clearly indicated. An extraction method able to produce a product for the market also needs to be considered.

\section{Ginkgo Biloba Extract EGb $761^{\circledR}$ : A Plant Extract Story with Varying Clinical Trial Outcomes}

The Ginkgo biloba (Ginkgoaceae) tree, also described as a living fossil, has existed on earth for more than 200 million years [128,129]. Ginkgo biloba extract EGb $761^{\circledR}$ is a standardized extract of Ginkgo biloba leaves, and has been widely studied in vitro and in vivo. The EGb 761 extract is well characterized and contains between $22-27 \%$ flavonol glycosides and terpene lactones (5-7\%), including ginkgolides (Figure 18) and biloballides [130]. It is one of the herbal extracts that has made it onto the market as a dietary supplement, requiring no approval by the FDA. Several clinical studies had shown a positive effect in the treatment of dementia. On its way to market, the Ginkgo biloba extract passed successfully through all the stages of drug research, as described in further detail below. Ginkgo biloba has become one of the most widely studied medicinal plant products [129]. 


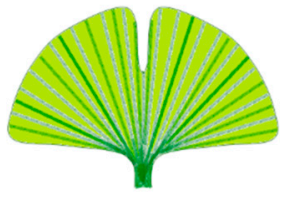

(a)

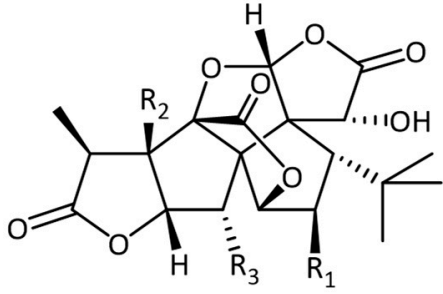

(b)

Figure 18. (a) Ginkgo leaf (b) ginkgolides.

\subsection{In Vitro Activity of Ginkgo Biloba}

Very early research into the in vitro antioxidant activity of Ginkgo biloba extracts found the presence of significant amount of phenolics, ferric ion reducing antioxidant power, copper chelating ability [131], peroxyl radical scavenging activity [132] and radical scavenging activity [133].

In vitro studies with PC12 neuronal cells investigating $A \beta(1-42)$ treatment (aggregated and soluble form) showed that Ginkgo biloba extracts have the potential to prevent $\mathrm{A} \beta$-induced ROS production, cytotoxicity, glucose uptake and apoptosis in PC12 cells. In addition, the formation of A $\beta$-derived diffusible neurotoxic ligands was prevented. These neurotoxic ligands have been suggested to mediate the neurotoxic effect of $A \beta[130]$.

\subsection{In Vivo Activity of Ginko Biloba}

In C. elegans, Ginkgo biloba extract EGb761 alleviates A $\beta$-induced pathological behavior, inhibits A $\beta$ oligomerization and deposits (not by reducing oxidative stress), and attenuates the basal as well as the induced levels of $\mathrm{H}_{2} \mathrm{O}_{2}$-related reactive oxygen species in $\mathrm{AD}$ models of neurodegeneration [134,135].

In a mouse trial reported by Liu et al. in 2015, further in-depth research of Ginkgo biloba extracts was carried out to elucidate the anti-inflammatory and underlying molecular pathways in APP-transgenic mice. The results showed inhibition of neuroinflammation, reduction of cognitive deficit and synaptic impairment, and enhanced autophagy, as well as the prevention of $A \beta$-induced microglial inflammatory activation [136].

\subsection{Clinical Trials of Ginko Biloba}

Rainer et al. [137] conducted a meta-analysis on three clinical studies from Austria. Findings showed a delay in "activities of daily living (ADL)" deterioration and overall cost savings compared to cholinesterase inhibitor treatment options. This study, however, only looked at ADL and the costs involved, focusing on the delay in progression towards higher care requirements; neuropsychiatric symptoms were not considered. This was assessed in a placebo-controlled, double-blind randomized trial by Herrschaft et al., where patients treated with EGb $761{ }^{\circledR}$ showed increased performance in cognitive tests and improved neuropsychiatric symptoms, with fewer changes seen in the placebo group. Also, secondary outcome measurements, including quality of life, ability to cope with demands of everyday life and clinicians' global judgement, were improved compared to placebo patients $[138,139]$.

In a different phase III randomized controlled clinical trial (NCT00010803), a $120 \mathrm{mg}$ BID dose was not able to prevent or delay the overall incidence rate of dementia or AD cases in participants with normal cognition/mild cognitive impairment [140].

A systematic review on the efficacy and adverse effects of Ginkgo biloba for cognitive impairment and dementia considered nine clinical trials (prior to 2014). Their findings showed that concentrations of $240 \mathrm{mg}$ /day were able to stabilize or slow the decline of cognition, function, behaviour and global change in patients with cognitive impairments [141].

A new clinical study into the cognitive function of patients with mild to moderate AD using 3 different interventions (Ginkgo biloba dispersible tablets vs. Donepezil vs. Ginkgo biloba dispersible 
tablets and Donepezil) is targeting enrolment of about 240 participants, and study started in March 2018. This Phase II/Phase III study will use different primary outcome measures, such as Mini-Mental State Examination, ADAS-cog, Magnetic Resonance Imaging and others to determine the effect of the three treatment options on AD patients. By doing so, they will hopefully be able to shed more light onto the use of Ginkgo biloba extracts and its effect on AD patients (NCT03090516).

\section{Conclusion/Future Perspectives}

Although pure natural products or plant extracts displaying antioxidant activity have shown very good results in in vitro and in vivo animal models, their clinical outcomes in human patients are still inconclusive and demonstrate limited success. This could partially be due to the fact that in clinical trials, mostly single compounds are studied. In contrast, investigation of plant extracts containing a variety of secondary metabolites is more common in studies prior to clinical studies. The combination of different active ingredients in extracts can lead to additive or synergistic effects, giving better antioxidant/disease-modifying activity [142,143]. This may be one reason why, for example, the clinical trial with Meganatural-Az Grapeseed Extract examined the effect of whole extracts compared to single compounds, such as resveratrol found in grapeseed extracts, which had shown positive effects in some AD trials [144]. In general, clinical trial outcomes for phytochemicals have been highly variable, perhaps due to the way these trials are conducted. Clinical trials look at a wide variety of participants with different environmental and genetic background and even different disease symptoms and sometimes stages of disease. It might be worth taking a closer look, not at the general significances of the whole participant population, but at single individuals, or smaller groups of individuals, which do show significant improvement and determine why they might be responding to the treatment when others are not. Although this would be associated with extra cost in trial, it could lead to a better understanding of the potential use of antioxidants in certain groups of patients, either with a certain genetic or environmental background, which would also lead to better understanding of the neurological disorder. In general, most clinical trials on natural antioxidants (i.e., natural products or plant extracts) have only looked at behavioral or cognitive improvements in patients, very few trials were found that actually assessed molecular markers of the disease or oxidative stress specifically.

Multi-target drugs and drug cocktails (combination of single compounds or extracts) also need to be further investigated. This consideration contradicts the one drug one disease (or one target one disease) approach which is currently used for many different disease treatments. However, as neurodegenerative disease can be associated with multiple cellular dysfunctions caused by various external and internal factors, a multi-target drug approach might be a better way forward, especially due to the complex nature of these diseases $[49,145]$. Multi-target drugs have received more attention in recent years, as evidenced by the drug approval of Namzaric in 2014 [9], which is a combination treatment of memantine hydrochloride (extended-release) and donepezil hydrochloride, which are a NMDA receptor antagonist and an AChE inhibitor, respectively. The multidrug treatment option was further investigated in a recent study by Admasu et al. [146] in C. elegans, in which combinations of currently FDA-approved drugs led to significant healthspan and lifespan elongations. Natural antioxidants (i.e., from natural products or plant extracts) could also fulfil this multi-target drug profile. They have shown antioxidant activity, but have also presented other activities beneficial to neuronal health, such as metal chelating, anti-inflammatory, AChE inhibition or anti-protein aggregation activities. Another option is the use of FDA-approved AChE inhibitors such as donepezil, rivastigmine, or galantamine, or even less-active AChE inhibitors in conjunction with natural antioxidants. Drug mixtures with moderate activities acting on two or more targets might be more effective than a single highly effective but selective drug acting on a single target [147].

Apart from this, a better understanding of the mechanisms causing the disease are necessary. For most neurodegenerative diseases, the exact cause of the disease is still only partially understood, if not completely unclear. Some of them, e.g., PD, can be caused by environmental or genetic factors, while for others, such as HD, the cause-a genetic mutation in the huntingtin gene-is well known, 
but the exact disease mechanism/pathway is still unclear, as the behavior of the mutated protein has not been completely elucidated. Very often, the reasons why particularly neurons are affected by, for example, mutated proteins, is still unclear. Constant research into improved animal models for these diseases might help with both a better understanding of the neurological disorder and the search for potential drugs. A special collection of articles on "Neurodegeneration: from Models to Mechanisms to Therapies" from 2017 covers a few of the important issues in different neurodegenerative disease [52].

At a recent national ataxia foundation conference, the issue of pre-treatment versus treatment once the disease has developed was brought to attention. Several people agreed that pre-treatment might be a possible option. This, however, would make it necessary to find better biomarkers that would make it possible to determine people who might turn into patients later on. In this case, we might also find responders and non-responders. Non-responders would then have the chance to move into treatment options, which have proven successful once the disease showed initial symptoms. Natural product or plant extract antioxidants might be a great option for potential pre-symptom treatment, as they are most often not associated with side effects and are well accepted in the population. Long-term trial would need to verify this, of course.

In conclusion, plant natural products and extracts have shown several positive effects in in vitro, as well as in vivo, neurodegenrative disease models. However, translation to clinical trials is lacking in positive outcomes. Further reseach into the pathology and mechanisms of these neurodegenerative diseases might help to elucidate the lack of success of plant extratcs and natural products in human patients.

Author Contributions: P.K.T.L. and F.P. conceived and designed this work. F.P. wrote the review.

Funding: The authors are grateful for a funding from Tenovus Scotland (Grampian), who provided a 4-year scholarship (Moulton-Barrett Research Scholarship), which supported F. Pohl for her research.

Acknowledgments: The authors wish to thank Eoin Cowie for reading and providing comments on this manuscript.

Conflicts of Interest: The authors declare no conflict of interest.

$\begin{array}{ll}\text { Abbreviations } & \\ \text { 6-OHDA } & \text { 6-hydroxydopamin } \\ \text { AAPH } & \text { 2,2'-Azobis(2-amidinopropane) dihydrochloride } \\ \text { ABTS } & \text { 2,2'-azino-bis(3-ethylbenzothiazoline-6-sulphonic acid) } \\ \text { AChE } & \text { Acetylcholinesterase } \\ \text { AD } & \text { Alzheimer's disease } \\ \text { ADAS-Cog } & \text { AD Assessment Scale cognitive subscale } \\ \text { ADL } & \text { activities of daily living } \\ \text { AEP } & \text { asparagine endopeptidase } \\ \text { ALS } & \text { Amyotrophic lateral sclerosis/MND motor neurone disease } \\ \text { APP } & \text { amyloid precursor protein } \\ \text { APP/PS1 } & \text { AD mouse model } \\ \text { A } \beta & \text { amyloid beta } \\ \alpha-s y n & \text { alpha-synuclein } \\ \text { CAT } & \text { catalase } \\ \text { CCl } & \text { carbon tetrachloride } \\ \text { CHP } & \text { cumene hydroperoxide } \\ \text { CRISP } & \text { clustered regularly interspaced short palindromic repeats } \\ \text { DPPH } & \text { 2,2-diphenylpicrylhydrazyl } \\ \text { ERK } & \text { extracellular signal-regulated kinase } \\ \text { FDA } & \text { Food and Drug Administration } \\ \text { FTLD } & \text { frontotemporal lobar degeneration } \\ \text { GAE } & \text { gallic acid equivalence } \\ \text { GCLM } & \text { Glutamate-cysteine ligase regulatory subunit } \\ \text { GFP } & \text { green fluorescence protein } \\ \end{array}$




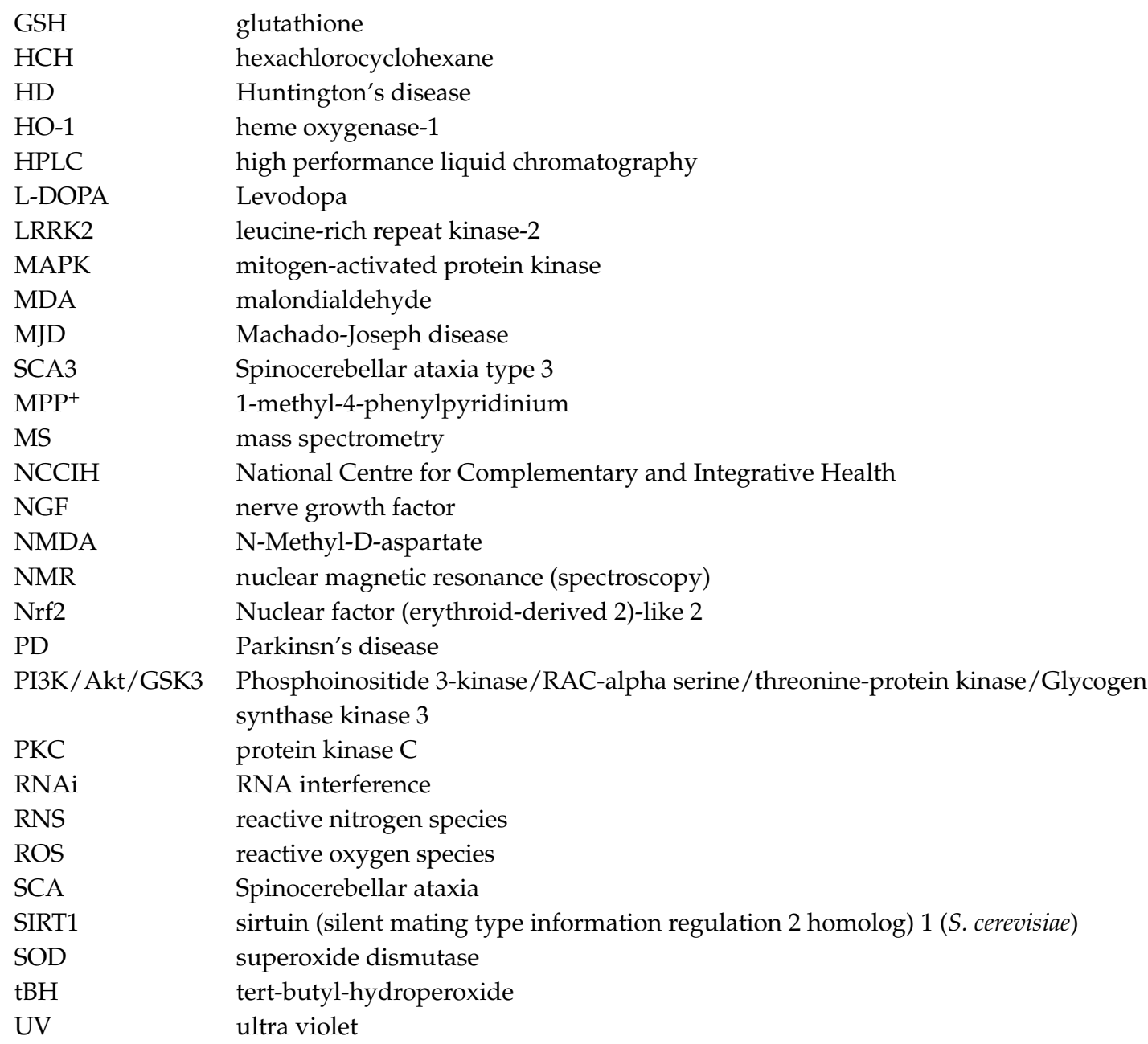

\section{References}

1. Kim, G.H.; Kim, J.E.; Rhie, S.J.; Yoon, S. The role of oxidative stress in neurodegenerative diseases. Exp. Neurobiol. 2015, 24, 325-340. [CrossRef] [PubMed]

2. Christensen, K.; Doblhammer, G.; Rau, R.; Vaupel, J.W. Ageing populations: The challenges ahead. Lancet 2009, 374, 1196-1208. [CrossRef]

3. Prince, M.; Guerchet, M.; Prina, M. World Alzheimer Report 2013; Alzheimer's Disease International: London, UK, 2013.

4. Dorsey, E.R.; Constantinescu, R.; Thompson, J.P.; Biglan, K.M.; Holloway, R.G.; Kieburtz, K.; Marshall, F.J.; Ravina, B.M.; Schifitto, G.; Siderowf, A.; et al. Projected number of people with Parkinson disease in the most populous nations, 2005 through 2030. Neurology 2007, 68, 384-386. [CrossRef] [PubMed]

5. Newman, D.J.; Cragg, G.M. Natural products as sources of new drugs over the 30 years from 1981 to 2010. J. Nat. Prod. 2012, 75, 311-335. [CrossRef]

6. Prince, M.; Jackson, J. World Alzheimer Report; Alzheimer's Disease International: London, UK, 2009.

7. Rafii, M.S.; Aisen, P.S. Recent developments in Alzheimer's disease therapeutics. BMC Med. $2009,7,7$. [CrossRef] [PubMed]

8. Cummings, J.L.; Morstorf, T.; Zhong, K. Alzheimer's disease drug-development pipeline: Few candidates, frequent failures. Alzheimers Res. Ther. 2014, 6, 37. [CrossRef] [PubMed]

9. Dunn, W.H. (FDA) Namzaric Drug Approval (NDA 206439) 2014. Available online: https:/ / www.accessdata. fda.gov/scripts/cder/daf/in (accessed on 8 December 2018).

10. Espinoza-Fonseca, L.M. The benefits of the multi-target approach in drug design and discovery. Bioorg. Med. Chem. 2006, 14, 896-897. [CrossRef] [PubMed] 
11. CenterWatch FDA Approved Drugs by Medical Condition. Available online: https://www.centerwatch. com/drug-information/fda-approved-drugs/medical-conditions/ (accessed on 8 November 2018).

12. Aguzzi, A.; Lakkaraju, A.K.K.; Frontzek, K. Toward therapy of human prion diseases. Annu. Rev. Pharmacol. Toxicol. 2018, 58, 331-351. [CrossRef] [PubMed]

13. Sureda, F.X.; Junyent, F.; Verdaguer, E.; Auladell, C.; Pelegri, C.; Vilaplana, J.; Folch, J.; Canudas, A.M.; Zarate, C.B.; Pallès, M.; et al. Antiapoptotic drugs: A therapautic strategy for the prevention of neurodegenerative diseases. Curr. Pharm. Des. 2011, 17, 230-245. [CrossRef] [PubMed]

14. Lublin, A.L.; Link, C.D. Alzheimer's disease drug discovery: in vivo screening using Caenorhabditis elegans as a model for $\beta$-amyloid peptide-induced toxicity. Drug Discov. Today Technol. 2013, 10, e115-e119. [CrossRef] [PubMed]

15. Bautista-Aguilera, O.M.; Esteban, G.; Chioua, M.; Nikolic, K.; Agbaba, D.; Moraleda, I.; Iriepa, I.; Soriano, E.; Samadi, A.; Unzeta, M.; et al. Multipotent cholinesterase/monoamine oxidase inhibitors for the treatment of Alzheimer's disease: Design, synthesis, biochemical evaluation, ADMET, molecular modeling, and QSAR analysis of novel donepezil-pyridyl hybrids. Drug Des. Devel. Ther. 2014, 8, 1893-1910. [PubMed]

16. Uttara, B.; Singh, A.V.; Zamboni, P.; Mahajan, R.T. Oxidative stress and neurodegenerative diseases: A review of upstream and downstream antioxidant therapeutic options. Curr. Neuropharmacol. 2009, 7, 65-74. [CrossRef] [PubMed]

17. Aliev, G.; Kaminsky, Y.G.; Bragin, V.; Kosenko, E.A.; Klochkov, S.G.; Bachurin, S.O.; Benberin, V.V. Flavones from the root of Scutellaria baicalensis Georgi-drug of the future in neurodegeneration and neuroprotection? In Systems Biology of Free Radicals and Antioxidants; Laher, I., Ed.; Springer: Berlin, Germany, 2014; pp. 2305-2323.

18. Zhang, Z.; Xie, M.; Ye, K. Asparagine endopeptidase is an innovative therapeutic target for neurodegenerative diseases. Expert Opin. Ther. Targets 2016, 20, 1237-1245. [CrossRef] [PubMed]

19. Ross, C.A.; Poirier, M.A. Protein aggregation and neurodegenerative disease. Nat. Med. 2004, 10, S10-S17. [CrossRef] [PubMed]

20. Zunke, F.; Moise, A.C.; Belur, N.R.; Gelyana, E.; Stojkovska, I.; Dzaferbegovic, H.; Toker, N.J.; Jeon, S.; Fredriksen, K.; Mazzulli, J.R. Reversible conformational conversion of $\alpha$-synuclein into toxic assemblies by glucosylceramide. Neuron 2018, 97, 92-107.e10. [CrossRef] [PubMed]

21. Sharma, N.K.; Mathur, D.; Vinish, M.; Sharma, R.; Bhatia, K.; Pannu, V.; Anand, A. Hype and hopes of stem cell research in neurodegenerative diseases. In Regenerative Medicine: Laboratory to Clinic; Springer: Singapore, 2017; pp. 209-231.

22. Petrou, P.; Gothelf, Y.; Argov, Z.; Gotkine, M.; Levy, Y.S.; Kassis, I.; Vaknin-Dembinsky, A.; Ben-Hur, T.; Offen, D.; Abramsky, O.; et al. Safety and clinical effects of mesenchymal stem cells secreting neurotrophic factor transplantation in patients with amyotrophic lateral sclerosis. JAMA Neurol. 2016, 73, 337-344. [CrossRef]

23. Tuszynski, M.H.; Thal, L.; Pay, M.; Salmon, D.P.; Bakay, R.; Patel, P.; Blesch, A.; Vahlsing, H.L.; Ho, G.; Tong, G.; et al. A phase 1 clinical trial of nerve growth factor gene therapy for Alzheimer disease. Nat. Med. 2005, 11, 551-555. [CrossRef]

24. Harman, D. Aging: A theory based on free radical and radiation chemistry. J. Gerontol. 1956, 11, $298-300$. [CrossRef]

25. Patten, D.A.; Germain, M.; Kelly, M.A.; Slack, R.S. Reactive oxygen species: Stuck in the middle of neurodegeneration. J. Alzheimer's Dis. 2010, 20, S357-S367. [CrossRef]

26. Knight, J.A. Free radicals: Their history and current status in aging and disease. Ann. Clin. Lab. Sci. 1998, 28, 331-346.

27. Hornykiewicz, O. A brief history of levodopa. J. Neurol. 2010, 257, 249-252. [CrossRef] [PubMed]

28. Lahlou, M. The success of natural products in drug discovery. Pharmacol. Pharm. 2013, 4, 17-31. [CrossRef]

29. Poljsak, B.; Šuput, D.; Milisav, I. Achieving the balance between ROS and antioxidants: When to use the synthetic antioxidants. Oxid. Med. Cell. Longev. 2013, 2013, 956792. [CrossRef] [PubMed]

30. Gandhi, S.; Abramov, A.Y. Mechanism of oxidative stress in neurodegeneration. Oxid. Med. Cell. Longev. 2012, 2012, 428010. [CrossRef] [PubMed]

31. Tang, L.-L.; Wang, R.; Tang, X.-C. Huperzine A protects SHSY5Y neuroblastoma cells against oxidative stress damage via nerve growth factor production. Eur. J. Pharmacol. 2005, 519, 9-15. [CrossRef] [PubMed]

32. Choi, D.-Y.; Lee, Y.-J.; Hong, J.T.; Lee, H.-J. Antioxidant properties of natural polyphenols and their therapeutic potentials for Alzheimer's disease. Brain Res. Bull. 2012, 87, 144-153. [CrossRef] [PubMed] 
33. Chege, P.M.; McColl, G. Caenorhabditis elegans: A model to investigate oxidative stress and metal dyshomeostasis in Parkinson's disease. Front. Aging Neurosci. 2014, 6, 1-15. [CrossRef]

34. Gilgun-Sherki, Y.; Melamed, E.; Offen, D. Oxidative stress induced-neurodegenerative diseases: The need for antioxidants that penetrate the blood brain barrier. Neuropharmacology 2001, 40, 959-975. [CrossRef]

35. Augustyniak, A.; Bartosz, G.; Čipak, A.; Duburs, G.; Horáková, L.; Łuczaj, W.; Majekova, M.; Odysseos, A.D.; Rackova, L.; Skrzydlewska, E.; et al. Natural and synthetic antioxidants: An updated overview. Free Radic. Res. 2010, 44, 1216-1262. [CrossRef]

36. Carocho, M.; Ferreira, I.C.F.R. A review on antioxidants, prooxidants and related controversy: Natural and synthetic compounds, screening and analysis methodologies and future perspectives. Food Chem. Toxicol. 2013, 51, 15-25. [CrossRef]

37. Newman, D.J.; Cragg, G.M. Natural products as sources of new drugs from 1981 to 2014. J. Nat. Prod. 2016, 79, 629-661. [CrossRef] [PubMed]

38. Harvey, A.L.; Edrada-Ebel, R.; Quinn, R.J. The re-emergence of natural products for drug discovery in the genomics era. Nat. Rev. Drug Discov. 2015, 14, 111-129. [CrossRef] [PubMed]

39. Mathur, S.; Hoskins, C. Drug development: Lessons from nature. Biomed. Rep. 2017, 6, 612-614. [CrossRef] [PubMed]

40. Wink, M. Introduction: Biochemistry, physiology and ecological functions of secondary metabolites. In Annual Plant Reviews Volume 40 Biochemistry of Plant Secondary Metabolites; Wink, M., Ed.; Wiley-Blackwell: West Sussex, Oxford UK, 2010; pp. 1-19.

41. Harbourne, N.; Marete, E.; Jacquier, J.C.; O'Riordan, D. Stability of phytochemicals as sources of anti-inflammatory nutraceuticals in beverages-A review. Food Res. Int. 2013, 50, 480-486. [CrossRef]

42. Khlifi, D.; Sghaier, R.M. Anti-inflammatory and acetylcholinesterase inhibition activities of Globularia Alypum. J. Med. Bioeng. 2013, 2, 232-237. [CrossRef]

43. Muthaiyah, B.; Essa, M.M.; Chauhan, V.; Chauhan, A. Protective effects of walnut extract against amyloid beta peptide-induced cell death and oxidative stress in PC12 cells. Neurochem. Res. 2011, 36, 2096-2103. [CrossRef] [PubMed]

44. Saeidnia, S.; Gohari, A.R. Importance of Brassica napus as a medicinal food plant. J. Med. Plants Res. 2012, 6, 2700-2703. [CrossRef]

45. Yue, J.; Shang, P.; Wang, G.; Liu, D.; Xu, L.; Zhou, W. Nutritional and antioxidant properties of rapeseed (Brassica Napus) cultivars with high and low erucic acid content. J. Food Nutr. Res. 2014, 2, 918-924. [CrossRef]

46. Wink, M.; Abbas, S. Epigallocatechin gallate (EGCG) from green tea (Camellia sinensis) and other natural products mediate stress resistance and slows down aging processes in caenorhabditis elegans. In Tea in Health and Disease Prevention; Preedy, V.R., Ed.; Elsevier Science Publishing Co., Inc.: London, UK, 2013; pp. 1105-1115.

47. Sun-Waterhouse, D. The development of fruit-based functional foods targeting the health and wellness market: A review. Int. J. Food Sci. Technol. 2011, 46, 899-920. [CrossRef]

48. Fontana, A.R.; Antoniolli, A.; Bottini, R. Grape pomace as a sustainable source of bioactive compounds: Extraction, characterization, and biotechnological applications of phenolics. J. Agric. Food Chem. 2013, 61, 8987-9003. [CrossRef]

49. Brusotti, G.; Cesari, I.; Dentamaro, A.; Caccialanza, G.; Massolini, G. Isolation and characterization of bioactive compounds from plant resources: The role of analysis in the ethnopharmacological approach. J. Pharm. Biomed. Anal. 2014, 87, 218-228. [CrossRef] [PubMed]

50. Upadhyay, S.; Dixit, M. Role of polyphenols and other phytochemicals on molecular signaling. Oxid. Med. Cell. Longev. 2015, 2015, 504253. [CrossRef] [PubMed]

51. Björkman, M.; Klingen, I.; Birch, A.N.E.; Bones, A.M.; Bruce, T.J.A.; Johansen, T.J.; Meadow, R.; Mølmann, J.; Seljåsen, R.; Smart, L.E.; et al. Phytochemicals of Brassicaceae in plant protection and human health-influences of climate, environment and agronomic practice. Phytochemistry 2011, 72, 538-556. [CrossRef] [PubMed]

52. Gitler, A.D.; Dhillon, P.; Shorter, J. Neurodegenerative disease: Models, mechanisms, and a new hope. Dis. Model. Mech. 2017, 10, 499-502. [CrossRef] [PubMed] 
53. Bahmad, H.; Hadadeh, O.; Chamaa, F.; Cheaito, K.; Darwish, B.; Makkawi, A.-K.; Abou-Kheir, W. Modeling human neurological and neurodegenerative diseases: From induced pluripotent stem cells to neuronal differentiation and its applications in neurotrauma. Front. Mol. Neurosci. 2017, 10, 1-17. [CrossRef] [PubMed]

54. Jorfi, M.; D'Avanzo, C.; Kim, D.Y.; Irimia, D. Three-dimensional models of the human brain development and diseases. Adv. Healthc. Mater. 2018, 7, 1-20. [CrossRef] [PubMed]

55. Marton, R.M.; Paşca, S.P. Neural differentiation in the third dimension: Generating a human midbrain. Cell. Stem Cell. 2016, 19, 145-146. [CrossRef] [PubMed]

56. Kovalevich, J.; Langford, D. Considerations for the use of SH-SY5Y neuroblastoma cells in neurobiology. In Neuronal Cell Culture: Methods and Protocols; Amini, S., White, K.M., Eds.; Springer Science + Business Media: New York, NY, USA 2013; pp. 9-21.

57. Gordon, J.; Amini, S.; White, M.K. General overview of neuronal cell culture. Methods Mol. Biol. 2013, 1078, 1-8. [CrossRef] [PubMed]

58. Cheon, S.-M.; Jang, I.; Lee, M.-H.; Kim, D.K.; Jeon, H.; Cha, D.S. Sorbus alnifolia protects dopaminergic neurodegeneration in Caenorhabditis elegans. Pharm. Biol. 2016, 55, 481-486. [CrossRef] [PubMed]

59. Kim, M.-B.; Park, J.-S.; Lim, S.-B. Antioxidant activity and cell toxicity of pressurised liquid extracts from 20 selected plant species in Jeju, Korea. Food Chem. 2010, 122, 546-552. [CrossRef]

60. Lee, B.K.; Jung, Y.-S. Allium cepa extract and quercetin protect neuronal cells from oxidative stress via PKC- $\varepsilon$ inactivation/ERK1/2 activation. Oxid. Med. Cell. Longev. 2016, 2016, 2495624. [CrossRef] [PubMed]

61. Fredotovíc, Ž.; Šprung, M.; Soldo, B.; Ljubenkov, I.; Budić-Leto, I.; Bilušić, T.; Cikeš-Čulić, V.; Puizina, J. Chemical composition and biological activity of allium cepa L. and Allium $\times$ cornutum (Clementi ex Visiani 1842) methanolic extracts. Molecules 2017, 22, 448. [CrossRef] [PubMed]

62. Hwang, I.K.; Lee, C.H.; Yoo, K.-Y.; Choi, J.H.; Park, O.K.; Lim, S.S.; Kang, I.-J.; Kwon, D.Y.; Park, J.; Yi, J.-S.; et al. Neuroprotective effects of onion extract and quercetin against ischemic neuronal damage in the gerbil hippocampus. J. Med. Food 2009, 12, 990-995. [CrossRef]

63. Bhanot, A.; Shri, R. A comparative profile of methanol extracts of Allium cepa and Allium sativum in diabetic neuropathy in mice. Pharmacogn. Res. 2010, 2, 374-384. [CrossRef]

64. Jaiswal, N.; Rizvi, S.I. Onion extract (Allium cepa L.), quercetin and catechin up-regulate paraoxonase 1 activity with concomitant protection against low-density lipoprotein oxidation in male Wistar rats subjected to oxidative stress. J. Sci. Food Agric. 2014, 94, 2752-2757. [CrossRef] [PubMed]

65. Pate, K.M.; Rogers, M.; Reed, J.W.; van der Munnik, N.; Vance, S.Z.; Moss, M.A. Anthoxanthin polyphenols attenuate a $\beta$ oligomer-induced neuronal responses associated with Alzheimer's disease. CNS Neurosci. Ther. 2017, 23, 135-144. [CrossRef] [PubMed]

66. Paredes-Gonzalez, X.; Fuentes, F.; Jeffery, S.; Saw, C.L.-L.; Shu, L.; Su, Z.-Y.; Kong, A.-N.T. Induction of NRF2-mediated gene expression by dietary phytochemical flavones apigenin and luteolin. Biopharm. Drug Dispos. 2015, 36, 440-451. [CrossRef]

67. Procházková, D.; Boušová, I.; Wilhelmová, N. Antioxidant and prooxidant properties of flavonoids. Fitoterapia 2011, 82, 513-523. [CrossRef]

68. Angeles, D.C.; Ho, P.; Dymock, B.W.; Lim, K.-L.; Zhou, Z.-D.; Tan, E.-K. Antioxidants inhibit neuronal toxicity in Parkinson's disease-linked LRRK2. Ann. Clin. Transl. Neurol. 2016, 3, 288-294. [CrossRef]

69. Piotrowska, H.; Kucinska, M.; Murias, M. Biological activity of piceatannol: Leaving the shadow of resveratrol. Mutat. Res. Mutat. Res. 2012, 750, 60-82. [CrossRef] [PubMed]

70. Farkhondeh, T.; Samarghandian, S.; Shahri, A.M.P.; Samini, F. The neuroprotective effects of thymoquinone: A review. Dose. Response 2018, 16, 1559325818761455. [CrossRef] [PubMed]

71. Kim, J.-S.; Ha, T.-Y.; Ahn, J.; Kim, S. Analysis and distribution of esculetin in plasma and tissues of rats after oral administration. Prev. Nutr. Food Sci. 2014, 19, 321-326. [CrossRef] [PubMed]

72. Kumar, S.S.; Priyadarsini, K.I.; Sainis, K.B. Inhibition of peroxynitrite-mediated reactions by vanillin. J. Agric. Food Chem. 2004, 52, 139-145. [CrossRef] [PubMed]

73. Tai, A.; Sawano, T.; Yazama, F.; Ito, H. Evaluation of antioxidant activity of vanillin by using multiple antioxidant assays. Biochim. Biophys. Acta-Gen. Subj. 2011, 1810, 170-177. [CrossRef] [PubMed]

74. Scipioni, M.; Kay, G.; Megson, I.; Kong Thoo Lin, P. Novel vanillin derivatives: Synthesis, anti-oxidant, DNA and cellular protection properties. Eur. J. Med. Chem. 2018, 143, 745-754. [CrossRef] [PubMed] 
75. Wu, S.-L.; Chen, J.-C.; Li, C.-C.; Lo, H.-Y.; Ho, T.-Y.; Hsiang, C.-Y. Vanillin improves and prevents trinitrobenzene sulfonic acid-induced colitis in mice. J. Pharmacol. Exp. Ther. 2009, 330, 370-376. [CrossRef]

76. Dhanalakshmi, C.; Manivasagam, T.; Nataraj, J.; Justin Thenmozhi, A.; Essa, M.M. Neurosupportive role of vanillin, a natural phenolic compound, on rotenone induced neurotoxicity in SH-SY5Y neuroblastoma cells. Evid. Based Complement. Alternat. Med. 2015, 2015, 626028. [CrossRef]

77. McGurk, L.; Berson, A.; Bonini, N.M. Drosophila as an in vivo model for human neurodegenerative disease. Genetics 2015, 201, 377-402. [CrossRef]

78. Jahromi, S.R.; Haddadi, M.; Shivanandappa, T.; Ramesh, S.R. Attenuation of neuromotor deficits by natural antioxidants of Decalepis hamiltonii in transgenic Drosophila model of Parkinson's disease. Neuroscience 2015, 293, 136-150. [CrossRef]

79. Srivastava, A.; Harish, S.R.; Shivanandappa, T. Antioxidant activity of the roots of Decalepis hamiltonii (Wight \& Arn.). LWT—Food Sci. Technol. 2006, 39, 1059-1065. [CrossRef]

80. Srivastava, A.; Jagan Mohan Rao, L.; Shivanandappa, T. Isolation of ellagic acid from the aqueous extract of the roots of Decalepis hamiltonii: Antioxidant activity and cytoprotective effect. Food Chem. 2007, 103, 224-233. [CrossRef]

81. Briffa, M.; Ghio, S.; Neuner, J.; Gauci, A.J.; Cacciottolo, R.; Marchal, C.; Caruana, M.; Cullin, C.; Vassallo, N.; Cauchi, R.J. Extracts from two ubiquitous Mediterranean plants ameliorate cellular and animal models of neurodegenerative proteinopathies. Neurosci. Lett. 2017, 638, 12-20. [CrossRef] [PubMed]

82. Osuna-Martínez, U.; Reyes-Esparza, J.; Rodríguez-Fragoso, L. Cactus (Opuntia ficus-indica): A review on its antioxidants properties and potential pharmacological use in chronic diseases. Nat. Prod. Chem. Res. 2014, 2, 6. [CrossRef]

83. Khaled, N.; Hiba, M.; Asma, C. Antioxidant and antifungal activities of Padina Pavonica and Sargassum Vulgare from the Lebanese Mediterranean coast. Adv. Environ. Biol. 2012, 6, 42-48.

84. Alexander, A.G.; Marfil, V.; Li, C. Use of Caenorhabditis elegans as a model to study Alzheimer's disease and other neurodegenerative diseases. Front. Genet. 2014, 5, 1-21. [CrossRef]

85. Chen, X.; Barclay, J.W.; Burgoyne, R.D.; Morgan, A. Using C. elegans to discover therapeutic compounds for ageing-associated neurodegenerative diseases. Chem. Cent. J. 2015, 9, 1-20. [CrossRef]

86. Wei, C.-C.; Yu, C.-W.; Yen, P.-L.; Lin, H.-Y.; Chang, S.-T.; Hsu, F.-L.; Liao, V.H.-C. Antioxidant activity, delayed aging, and reduced amyloid- $\beta$ toxicity of methanol extracts of tea seed pomace from Camellia tenuifolia. J. Agric. Food Chem. 2014, 62, 10701-10707. [CrossRef]

87. Pohl, F.; Goua, M.; Bermano, G.; Russell, W.R.; Scobbie, L.; Maciel, P.; Kong Thoo Lin, P. Revalorisation of rapeseed pomace extracts: An in vitro study into its anti-oxidant and DNA protective properties. Food Chem. 2018, 239, 323-332. [CrossRef]

88. Pohl, F.; Goua, M.; Bermano, G.; Russell, W.R.; Maciel, P.; Kong Thoo Lin, P. Study into the polyphenol content and antioxidant activity of rapeseed pomace extracts. Proc. Nutr. Soc. 2016, 75, E59. [CrossRef]

89. Eaton, S.L.; Wishart, T.M. Bridging the gap: Large animal models in neurodegenerative research. Mamm. Genome 2017, 28, 324-337. [CrossRef]

90. Dawson, T.M.; Golde, T.E.; Lagier-Tourenne, C. Animal models of neurodegenerative diseases. Nat. Neurosci. 2018, 21, 1370-1379. [CrossRef] [PubMed]

91. Blandini, F.; Armentero, M.-T. Animal models of Parkinson's disease. FEBS J. 2012, 279, 1156-1166. [CrossRef] [PubMed]

92. Ingram, M.A.C.; Orr, H.T.; Clark, H.B. Genetically engineered mouse models of the trinucleotide-repeat spinocerebellar ataxias. Brain Res. Bull. 2012, 88, 33-42. [CrossRef] [PubMed]

93. Keifer, J.; Summers, C.H. Putting the "biology" back into "neurobiology": The strength of diversity in animal model systems for neuroscience research. Front. Syst. Neurosci. 2016, 10, 1-9. [CrossRef] [PubMed]

94. Ali, T.; Kim, T.; Rehman, S.U.; Khan, M.S.; Amin, F.U.; Khan, M.; Ikram, M.; Kim, M.O. Natural dietary supplementation of anthocyanins via PI3K/Akt/Nrf2/HO-1 pathways mitigate oxidative stress, neurodegeneration, and memory impairment in a mouse model of Alzheimer's disease. Mol. Neurobiol. 2017, 1-18. [CrossRef] [PubMed]

95. Gengler, S.; Hamilton, A.; Hölscher, C. Synaptic plasticity in the hippocampus of a APP/PS1 mouse model of Alzheimer's disease is impaired in old but not young mice. PLoS ONE 2010, 5, e9764. [CrossRef] [PubMed]

96. Koh, K.; Youn, J.E.; Kim, H.-S. Identification of anthocyanins in black soybean (Glycine max (L.) Merr.) varieties. J. Food Sci. Technol. 2014, 51, 377-381. [CrossRef] [PubMed] 
97. Gülçin, İ. Antioxidant properties of resveratrol: A structure-activity insight. Innov. Food Sci. Emerg. Technol. 2010, 11, 210-218. [CrossRef]

98. Cunha-Santos, J.; Duarte-Neves, J.; Carmona, V.; Guarente, L.; Pereira de Almeida, L.; Cavadas, C. Caloric restriction blocks neuropathology and motor deficits in Machado-Joseph disease mouse models through SIRT1 pathway. Nat. Commun. 2016, 7, 11445. [CrossRef]

99. Tellone, E.; Galtieri, A.; Russo, A.; Giardina, B.; Ficarra, S. Resveratrol: A focus on several neurodegenerative diseases. Oxid. Med. Cell. Longev. 2015, 2015,1-14. [CrossRef]

100. Mori, T.; Koyama, N.; Tan, J.; Segawa, T.; Maeda, M.; Town, T. Combination therapy with octyl gallate and ferulic acid improves cognition and neurodegeneration in a transgenic mouse model of Alzheimer's disease. J. Biol. Chem. 2017, 292, 11310-11325. [CrossRef] [PubMed]

101. Phonsatta, N.; Deetae, P.; Luangpituksa, P.; Grajeda-Iglesias, C.; Figueroa-Espinoza, M.C.; Le Comte, J.; Villeneuve, P.; Decker, E.A.; Visessanguan, W.; Panya, A. Comparison of antioxidant evaluation assays for investigating antioxidative activity of gallic acid and its alkyl esters in different food matrices. J. Agric. Food Chem. 2017, 65, 7509-7518. [CrossRef] [PubMed]

102. Szwajgier, D.; Borowiec, K.; Pustelniak, K. The neuroprotective effects of phenolic acids: Molecular mechanism of action. Nutrients 2017, 9, 477. [CrossRef]

103. Kikuzaki, H.; Hisamoto, M.; Hirose, K.; Akiyama, K.; Taniguchi, H. Antioxidant properties of ferulic acid and its related compounds. J. Agric. Food Chem. 2002, 50, 2161-2168. [CrossRef] [PubMed]

104. Haque, E.; Javed, H.; Azimullah, S.; Abul Khair, S.B.; Ojha, S. Neuroprotective potential of ferulic acid in the rotenone model of Parkinson's disease. Drug Des. Devel. Ther. 2015, 9, 5499-5510. [CrossRef]

105. Chen, C. Sinapic acid and its derivatives as medicine in oxidative stress-induced diseases and aging. Oxid. Med. Cell. Longev. 2015, 1-10. [CrossRef]

106. Zare, K.; Eidi, A.; Roghani, M.; Rohani, A.H. The neuroprotective potential of sinapic acid in the 6-hydroxydopamine-induced hemi-parkinsonian rat. Metab. Brain Dis. 2015, 30, 205-213. [CrossRef]

107. Zhang, R.; Miao, Q.-W.; Zhu, C.-X.; Zhao, Y.; Liu, L.; Yang, J.; An, L. Sulforaphane ameliorates neurobehavioral deficits and protects the brain from amyloid $\beta$ deposits and peroxidation in mice with Alzheimer-like lesions. Am. J. Alzheimers Dis. Other Demen. 2015, 30, 183-191. [CrossRef]

108. Zhang, J.; Zhang, R.; Zhan, Z.; Li, X.; Zhou, F.; Xing, A.; Jiang, C.; Chen, Y.; An, L. Beneficial effects of sulforaphane treatment in Alzheimer's disease may be mediated through reduced HDAC1/3 and increased P75NTR expression. Front. Aging Neurosci. 2017, 9, 1-12. [CrossRef]

109. Liu, Y.; Hettinger, C.L.; Zhang, D.; Rezvani, K.; Wang, X.; Wang, H. Sulforaphane enhances proteasomal and autophagic activities in mice and is a potential therapeutic reagent for Huntington's disease. J. Neurochem. 2014, 129, 539-547. [CrossRef]

110. Zhou, Q.; Chen, B.; Wang, X.; Wu, L.; Yang, Y.; Cheng, X.; Hu, Z.; Cai, X.; Yang, J.; Sun, X.; et al. Sulforaphane protects against rotenone-induced neurotoxicity in vivo: Involvement of the mTOR, Nrf2, and autophagy pathways. Sci. Rep. 2016, 6, 1-12. [CrossRef] [PubMed]

111. Petrillo, S.; Piermarini, E.; Pastore, A.; Vasco, G.; Schirinzi, T.; Carrozzo, R.; Bertini, E.; Piemonte, F. Nrf2-inducers counteract neurodegeneration in frataxin-silenced motor neurons: Disclosing new therapeutic targets for Friedreich's Ataxia. Int. J. Mol. Sci. 2017, 18, 2173. [CrossRef] [PubMed]

112. Houghton, C.A.; Fassett, R.G.; Coombes, J.S. Sulforaphane and other nutrigenomic Nrf2 activators: Can the Clinician's expectation be matched by the reality? Oxid. Med. Cell. Longev. 2016, 2016, 1-17. [CrossRef] [PubMed]

113. Visalli, G.; Facciolà, A.; Bertuccio, M.P.; Picerno, I.; Di Pietro, A. In vitro assessment of the indirect antioxidant activity of Sulforaphane in redox imbalance vanadium-induced. Nat. Prod. Res. 2017, 1-9. [CrossRef] [PubMed]

114. Braidy, N.; Selvaraju, S.; Essa, M.M.; Vaishnav, R.; Al-Adawi, S.; Al-Asmi, A.; Al-Senawi, H.; Abd Alrahman Alobaidy, A.; Lakhtakia, R.; Guillemin, G.J. Neuroprotective effects of a variety of pomegranate juice extracts against MPTP-induced cytotoxicity and oxidative stress in human primary neurons. Oxid. Med. Cell. Longev. 2013, 2013, 685909. [CrossRef] [PubMed]

115. Wu, Y.-L.; Chang, J.-C.; Lin, W.-Y.; Li, C.-C.; Hsieh, M.; Chen, H.-W.; Wang, T.-S.; Liu, C.-S.; Liu, K.-L. Treatment with caffeic acid and resveratrol alleviates oxidative stress induced neurotoxicity in cell and drosophila models of spinocerebellar ataxia type3. Sci. Rep. 2017, 7, 11641. [CrossRef] [PubMed]

116. Liu, J.; Banskota, A.; Critchley, A.; Hafting, J.; Prithiviraj, B. Neuroprotective effects of the cultivated chondrus crispus in a C. elegans model of Parkinson's disease. Mar. Drugs 2015, 13, 2250-2266. [CrossRef] [PubMed] 
117. Tsai, C.-W.; Tsai, R.-T.; Liu, S.-P.; Chen, C.-S.; Tsai, M.-C.; Chien, S.-H.; Hung, H.-S.; Lin, S.-Z.; Shyu, W.-C.; Fu, R.-H. Neuroprotective effects of betulin in pharmacological and transgenic Caenorhabditis elegans models of Parkinson's disease. Cell. Transplant. 2017, 26, 1903-1918. [CrossRef]

118. Lee, H.E.; Kim, D.H.; Park, S.J.; Kim, J.M.; Lee, Y.W.; Jung, J.M.; Lee, C.H.; Hong, J.G.; Liu, X.; Cai, M.; et al. Neuroprotective effect of sinapic acid in a mouse model of amyloid $\beta(1-42)$ protein-induced Alzheimer's disease. Pharmacol. Biochem. Behav. 2012, 103, 260-266. [CrossRef]

119. Karakida, F.; Ikeya, Y.; Tsunakawa, M.; Yamaguchi, T.; Ikarashi, Y.; Takeda, S.; Aburada, M. Cerebral protective and cognition-improving effects of sinapic acid in rodents. Biol. Pharm. Bull. 2007, 30, 514-519. [CrossRef]

120. Wang, J.; Santa-Maria, I.; Ho, L.; Ksiezak-Reding, H.; Ono, K.; Teplow, D.B.; Pasinetti, G.M. Grape derived polyphenols attenuate tau neuropathology in a mouse model of Alzheimer's disease. J. Alzheimers Dis. 2010, 22, 653-661. [CrossRef] [PubMed]

121. Xu, Q.; Langley, M.; Kanthasamy, A.G.; Reddy, M.B. Epigallocatechin gallate has a neurorescue effect in a mouse model of parkinson disease. J. Nutr. 2017, 147, 1926-1931. [CrossRef] [PubMed]

122. National Center for Complementary and Integrative Health (NIH) New NCCIH Funding Opportunities for Natural Product Clinical Trials Webinar Summary I NCCIH. Available online: https: / nccih.nih.gov /news / events / telecon/natural-product-CT-webinar (accessed on 9 June 2018).

123. Postuma, R.B.; Anang, J.; Pelletier, A.; Joseph, L.; Moscovich, M.; Grimes, D.; Furtado, S.; Munhoz, R.P.; Appel-Cresswell, S.; Moro, A.; et al. Caffeine as symptomatic treatment for Parkinson disease (Café-PD): A randomized trial. Neurology 2017, 89, 1795-1803. [CrossRef] [PubMed]

124. Huang, X.-T.; Qian, Z.-M.; He, X.; Gong, Q.; Wu, K.-C.; Jiang, L.-R.; Lu, L.-N.; Zhu, Z.; Zhang, H.-Y.; Yung, W.-H.; et al. Reducing iron in the brain: A novel pharmacologic mechanism of huperzine A in the treatment of Alzheimer's disease. Neurobiol. Aging 2014, 35, 1045-1054. [CrossRef] [PubMed]

125. Qian, Z.M.; Ke, Y. Huperzine A: Is it an effective disease-modifying drug for Alzheimer's disease? Front. Aging Neurosci. 2014, 6, 1-6. [CrossRef] [PubMed]

126. Rafii, M.S.; Walsh, S.; Little, J.T.; Behan, K.; Reynolds, B.; Ward, C.; Jin, S.; Thomas, R.; Aisen, P.S. A phase II trial of huperzine A in mild to moderate Alzheimer disease. Neurology 2011, 76, 1389-1394. [CrossRef] [PubMed]

127. Miroddi, M.; Navarra, M.; Quattropani, M.C.; Calapai, F.; Gangemi, S.; Calapai, G. Systematic review of clinical trials assessing pharmacological properties of Salvia species on memory, cognitive impairment and Alzheimer's disease. CNS Neurosci. Ther. 2014, 20, 485-495. [CrossRef]

128. DeFeudis, F.V.; Drieu, K. Ginkgo biloba extract (EGb 761) and CNS functions: Basic studies and clinical applications. Curr. Drug Targets 2000, 1, 25-58. [CrossRef]

129. Ude, C.; Schubert-Zsilavecz, M.; Wurglics, M. Ginkgo biloba extracts: A review of the pharmacokinetics of the active ingredients. Clin. Pharmacokinet. 2013, 52, 727-749. [CrossRef]

130. Yao, Z.; Drieu, K.; Papadopoulos, V. The Ginkgo biloba extract EGb 761 rescues the PC12 neuronal cells from $\beta$-amyloid-induced cell death by inhibiting the formation of $\beta$-amyloid-derived diffusible neurotoxic ligands. Brain Res. 2001, 889, 181-190. [CrossRef]

131. Lugasi, A.; Horvahovic, P.; Dworschák, E. Additional information to the in vitro antioxidant activity of Ginkgo biloba L. Phyther. Res. 1999, 13, 160-162. [CrossRef]

132. Maitra, I.; Marcocci, L.; Droy-Lefaix, M.T.; Packer, L. Peroxyl radical scavenging activity of Ginkgo biloba extract EGb 761. Biochem. Pharmacol. 1995, 49, 1649-1655. [CrossRef]

133. Ellnain-Wojtaszek, M.; Kruczyński, Z.; Kasprzak, J. Investigation of the free radical scavenging activity of Ginkgo biloba L. leaves. Fitoterapia 2003, 74, 1-6. [CrossRef]

134. Wu, Y.; Wu, Z.; Butko, P.; Christen, Y.; Lambert, M.P.; Klein, W.L.; Link, C.D.; Luo, Y. Amyloid-beta-induced pathological behaviors are suppressed by Ginkgo biloba extract EGb 761 and ginkgolides in transgenic Caenorhabditis elegans. J. Neurosci. 2006, 26, 13102-13113. [CrossRef] [PubMed]

135. Smith, J.V.; Luo, Y. Elevation of oxidative free radicals in Alzheimer's disease models can be attenuated by Ginkgo biloba extract EGb 761. J. Alzheimers Dis. 2003, 5, 287-300. [CrossRef]

136. Liu, X.; Hao, W.; Qin, Y.; Decker, Y.; Wang, X.; Burkart, M.; Schötz, K.; Menger, M.D.; Fassbender, K.; Liu, Y. Long-term treatment with Ginkgo biloba extract EGb 761 improves symptoms and pathology in a transgenic mouse model of Alzheimer's disease. Brain. Behav. Immun. 2015, 46, 121-131. [CrossRef]

137. Rainer, M.; Mucke, H.; Schlaefke, S. Ginkgo biloba extract EGb $761^{\circledR}$ in the treatment of dementia: A pharmacoeconomic analysis of the Austrian setting. Wien. Klin. Wochenschr. 2013, 125, 8-15. [CrossRef] 
138. Herrschaft, H.; Nacu, A.; Likhachev, S.; Sholomov, I.; Hoerr, R.; Schlaefke, S. Ginkgo biloba extract EGb $761^{\circledR}$ in dementia with neuropsychiatric features: A randomised, placebo-controlled trial to confirm the efficacy and safety of a daily dose of $240 \mathrm{mg}$. J. Psychiatr. Res. 2012, 46, 716-723. [CrossRef]

139. Hoerr, R.; Nacu, A. Neuropsychiatric symptoms in dementia and the effects of Ginkgo biloba extract EGb $761^{\circledR}$ treatment: Additional results from a 24-week randomized, placebo-controlled trial. Open Access J. Clin. Trials 2016, 8, 1-6. [CrossRef]

140. DeKosky, S.T.; Williamson, J.D.; Fitzpatrick, A.L.; Kronmal, R.A.; Ives, D.G.; Saxton, J.A.; Lopez, O.L.; Burke, G.; Carlson, M.C.; Fried, L.P.; et al. Ginkgo evaluation of memory (GEM) study investigators Ginkgo biloba for prevention of dementia: A randomized controlled trial. JAMA 2008, 300, 2253-2262. [CrossRef]

141. Tan, M.-S.; Yu, J.-T.; Tan, C.-C.; Wang, H.-F.; Meng, X.-F.; Wang, C.; Jiang, T.; Zhu, X.-C.; Tan, L. Efficacy and adverse effects of Ginkgo biloba for cognitive impairment and dementia: A systematic review and meta-analysis. J. Alzheimers Dis. 2015, 43, 589-603. [CrossRef] [PubMed]

142. Wang, S.; Wang, D.; Liu, Z. Synergistic, additive and antagonistic effects of Potentilla fruticosa combined with EGb761 on antioxidant capacities and the possible mechanism. Ind. Crops Prod. 2015, 67, 227-238. [CrossRef]

143. Skroza, D.; Generalić Mekinić, I.; Svilović, S.; Šimat, V.; Katalinić, V. Investigation of the potential synergistic effect of resveratrol with other phenolic compounds: A case of binary phenolic mixtures. J. Food Compos. Anal. 2015, 38, 13-18. [CrossRef]

144. Berman, A.Y.; Motechin, R.A.; Wiesenfeld, M.Y.; Holz, M.K. The therapeutic potential of resveratrol: A review of clinical trials. NPJ Precis. Oncol. 2017, 35, 1-9. [CrossRef] [PubMed]

145. Medina-Franco, J.L.; Giulianotti, M.A.; Welmaker, G.S.; Houghten, R.A. Shifting from the single to the multitarget paradigm in drug discovery. Drug Discov. Today 2013, 18, 495-501. [CrossRef] [PubMed]

146. Admasu, T.D.; Chaithanya Batchu, K.; Barardo, D.; Ng, L.F.; Lam, V.Y.M.; Xiao, L.; Cazenave-Gassiot, A.; Wenk, M.R.; Tolwinski, N.S.; Gruber, J. Drug synergy slows aging and improves healthspan through IGF and SREBP lipid signaling. Dev. Cell 2018, 1-13. [CrossRef] [PubMed]

147. de los Ríos, C.; Egea, J.; Marco-Contelles, J.; León, R.; Samadi, A.; Iriepa, I.; Moraleda, I.; Gálvez, E.; García, A.G.; López, M.G.; et al. Synthesis, inhibitory activity of cholinesterases, and neuroprotective profile of novel 1,8-naphthyidine derivatives. J. Med. Chem. 2010, 53, 5129-5143. [CrossRef] [PubMed]

Sample Availability: Samples of the compounds are not available from the authors.

(C) 2018 by the authors. Licensee MDPI, Basel, Switzerland. This article is an open access article distributed under the terms and conditions of the Creative Commons Attribution (CC BY) license (http:/ / creativecommons.org/licenses/by/4.0/). 